\title{
Diplomats in the Foxhole: The Evolution of the State Department During Irregular Conflicts
}

\author{
A Monograph \\ by \\ MAJ Nicholas C. Sinclair \\ United States Army

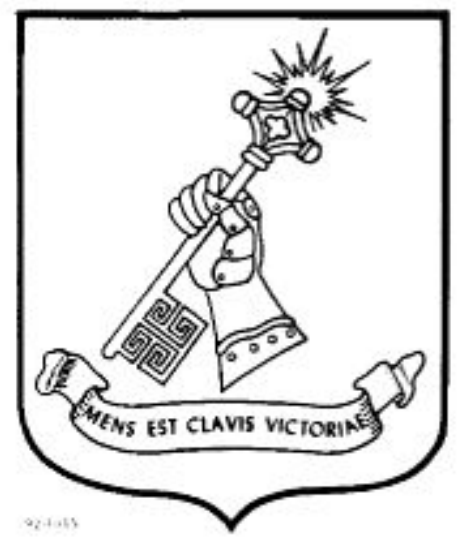 \\ School of Advanced Military Studies \\ United States Army Command and General Staff College \\ Fort Leavenworth, Kansas \\ 2014-01
}

Approved for public release; distribution is unlimited. 


\section{REPORT DOCUMENTATION PAGE}

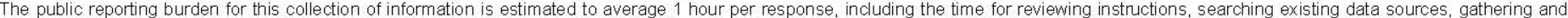

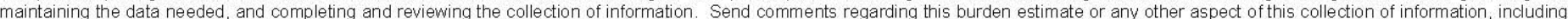

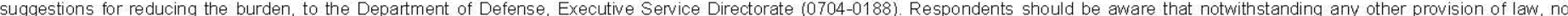
person shall be subject to any penalty for failing to comply with a collection of information if it does not display a currently valid OMB control number.

PLEASE DO NOT RETURN YOUR FORM TO THE ABOVE ORGANIZATION.
1. REPORT DATE (DD-MM-YYYY)
2. REPORT TYPE
22-05-2014
Monograph
3. DATES COVERED (From - To)

\section{TITLE AND SUBTTTLE}

Diplomats in the Foxhole: The Evolution of the State Department During Irregular

Conflicts

5b. GRANT NUMBER

5c. PROGRAM ELEMENT NUMBER

6. AUTHOR(S)

5d. PROJECT NUMBER

NICHOLAS C. SINCLAIR

MAJOR, USA

5e. TASK NUMBER

Armor

\section{5f. WORK UNIT NUMBER}

\section{PERFORMING ORGANIZATION NAME(S) AND ADDRESS(ES)}

U.S. Army Command and General Staff College

ATTN: ATZL-SWD-GD

100 Stimson Ave.

Fort Leavenworth, KS 66027-2301

9. SPONSORING/MONITORING AGENCY NAME(S) AND ADDRESS(ES)
8. PERFORMING ORGANIZATION REPORT NUMBER

10. SPONSOR/MONITOR'S ACRONYM(S)

11. SPONSOR/MONITOR'S REPORT NUMBER(S)

\section{DISTRIBUTION/AVAILABILITY STATEMENT}

Approved for public release; distribution is unlimited

\section{SUPPLEMENTARY NOTES}

\section{ABSTRACT}

This monograph identifies the process of organizational change demonstrated by the Department of State (DOS) when supporting U.S. efforts in an irregular warfare environment where there is a large Departement of Defense (DOD) general purpose force present. To successfully conduct operations abroad, United States Government (USG) interagency cooperation is necessary to achieve unity of effort towards a common aim. Although this seems obvious in theory, case studies analyzing Vietnam, Afghansitan and Iraq demonstrate that this is tremendously difficult to achieve in practice. This research shows that to adapt to this environment the DOS (1) creates ad hoc organizations, (2) establishes a unified command structure with the DOD and (3) uses local solutions to solve local problems. This monograph is intended to improve the U.S. Army professional understanding of the DOS so interagency cooperation in future political-military operations can be improved.

15. SUBJECT TERMS

Department of State, Interagency, Organizational Culture, Vietnam, Operation Enduring Freedom, Operation Iraqi Freedom

\begin{tabular}{|c|c|c|}
\hline \multicolumn{3}{|l|}{ 16. SECURITY CLASSIFICATION OF: } \\
\hline a. REPORT & b. ABSTRACT & c. THIS PAGE \\
Unclassified & Unclassified & Unclassified \\
\hline
\end{tabular}

\section{LIMITATIONOF ABSTRACT}

UU

\begin{tabular}{|l|} 
18. NUMBER \\
OF \\
PAGES \\
52
\end{tabular}

19a. NAME OF RESPONSIBLE PERSON

19b. TELEPHONE NUMBER (include area code) 


\section{MONOGRAPH APPROVAL PAGE}

Name of Candidate: MAJ Nicholas C. Sinclair

Monograph Title: Diplomats in the Foxhole: The Evolution of the State Department During Irregular Conflicts

Approved by:

Jeffrey J. Kubiak, Ph.D.

, Monograph Director

, Seminar Leader

Charles Evans, COL

, Director, School of Advanced Military Studies

Henry A. Arnold III, COL

Accepted this 23rd day of May 2014 by:

Robert F. Baumann, Ph.D.

, Director, Graduate Degree Programs

The opinions and conclusions expressed herein are those of the student author and do not necessarily represent the views of the U.S. Army Command and General Staff College or any other governmental agency. (References to this study should include the foregoing statement.) 


\begin{abstract}
DIPLOMATS IN THE FOXHOLE: THE EVOLUTION OF THE STATE DEPARTMENT

DURING IRREGULAR CONFLICTS, by MAJ Nicholas C. Sinclair, 52 pages.

This monograph identifies the process of organizational change demonstrated by the Department of State (DOS) when supporting U.S. efforts in an irregular warfare environment where there is a large Departement of Defense (DOD) general purpose force present. To successfully conduct operations abroad, United States Government (USG) interagency cooperation is necessary to achieve unity of effort towards a common aim. Although this seems obvious in theory, case studies analyzing Vietnam, Afghansitan and Iraq demonstrate that this is tremendously difficult to achieve in practice. This research shows that to adapt to this environment the DOS (1) creates ad hoc organizations, (2) establishes a unified command structure with the DOD and (3) uses local solutions to solve local problems. This monograph is intended to improve the U.S. Army professional understanding of the DOS so interagency cooperation in future political-military operations can be improved.
\end{abstract}




\section{ACKNOWLEDGMENTS}

This paper could not have been possible without the patriotism and sacrifice of the soldiers and statesmen supporting the United States of America for over two centuries. These men and women proudly recognized that civic duty to the greatest of all nations was as much a matter of devine selection as it was a personal choice.

I owe special thanks to a number of mentors and family who contributed to the production of this monograph. Dr. Jeff Kubiak, my monograph director, took time to aim me in the right direction and then took the training wheels off to let me develop my topic, providing assistance and course correction along the way. Dr. Seth Center, working in the Office of the Historian of the Department of State, took the time to communicate with someone he had never met and owed nothing and built the foundation of my literature review in a few short emails.

Finally to my wife, Jen, who served as my editor-in-chief and companion throughout the development of this project, thank you for helping me every step of the way. 


\section{TABLE OF CONTENTS}

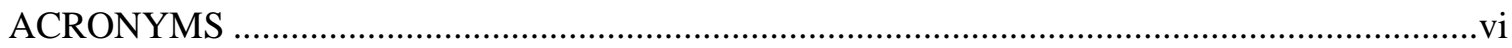

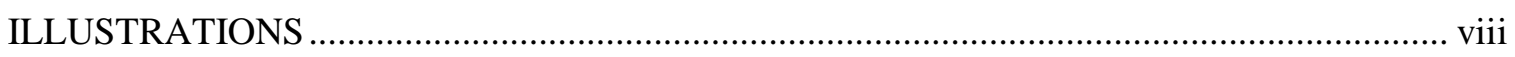

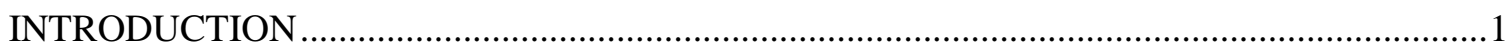

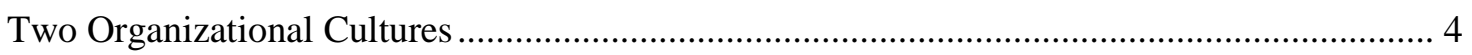

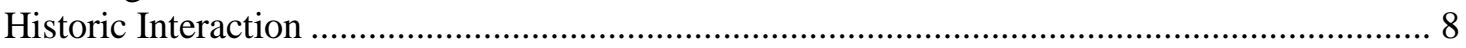

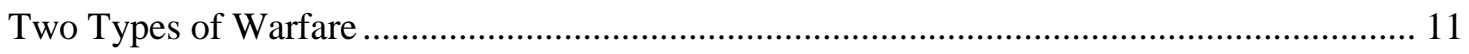

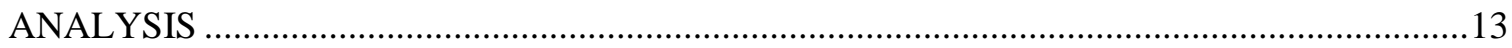

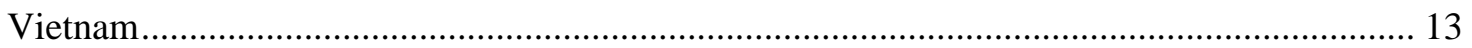

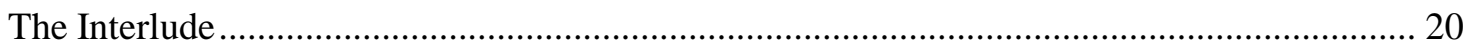

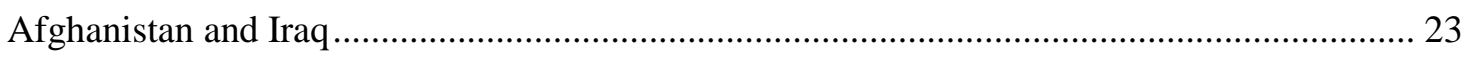

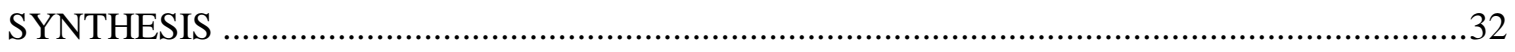

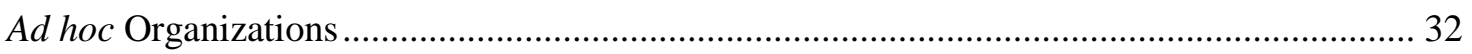

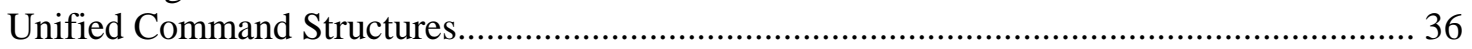

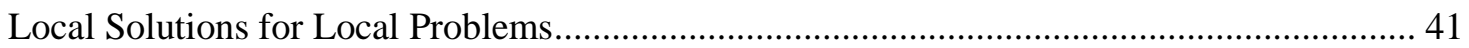

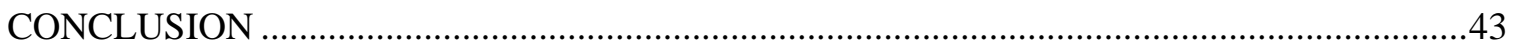

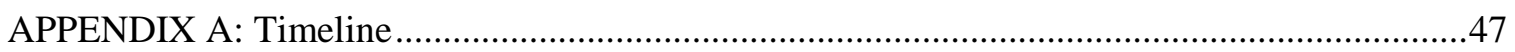

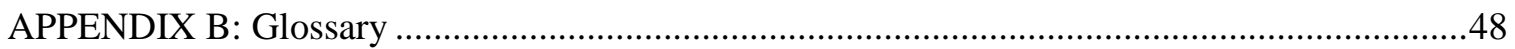

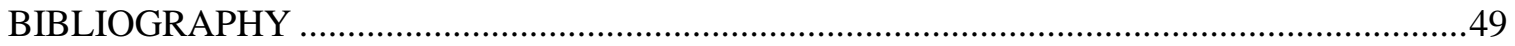




\section{ACRONYMS}

\begin{tabular}{|c|c|}
\hline AID/USAID & United States Agency for International Relief \\
\hline ARVN & Army of the Republic of Vietnam \\
\hline CIA & Central Intelligence Agency \\
\hline $\mathrm{COM}$ & Chief of Mission \\
\hline \multirow[t]{2}{*}{ COMUSMACV } & Commander United States Forces, Military Assistance Command, \\
\hline & Vietnam \\
\hline CORDS & Civil Operations and Revolutionary (later "Rural”) Development Support \\
\hline DepCORDS & Deputy to the Commander for CORDS \\
\hline DOD & Department of Defense \\
\hline DOS & Department of State \\
\hline DRV & Democratic Republic of Vietnam (North Vietnam) \\
\hline ePRT & embedded Provincial Reconstruction Team \\
\hline ESC & Executive Steering Committee \\
\hline FSO & Foreign Service Officer \\
\hline GVN & Government of the Republic of Vietnam (South Vietnam) \\
\hline HES & Hamlet Evaluation System \\
\hline ICAF & Interagency Conflict Assessment Framework \\
\hline IPA & Interagency Provincial Affairs \\
\hline ISAF & International Security Assistance Force \\
\hline MACV & Military Assistance Command Vietnam \\
\hline MAT & Mobile Advisory Team \\
\hline MiTT & Military Training Team \\
\hline MNF-I & Multi-National Forces-Iraq \\
\hline MNSTC-I & Multi-National Security Transition Command-Iraq \\
\hline
\end{tabular}




\begin{tabular}{|c|c|}
\hline NATO & North Atlantic Treaty Organization \\
\hline NCT & National Coordination Team \\
\hline NVA & North Vietnamese Army \\
\hline OEF & Operation Enduring Freedom \\
\hline OFFRO & Office of Foreign Relief and Rehabilitation Operations \\
\hline ORHA & Office for Reconstruction and Humanitarian Assistance \\
\hline OIF & Operation Iraqi Freedom \\
\hline OPA & Office of Provincial Affairs \\
\hline $\mathrm{PF}$ & Popular Forces \\
\hline $\mathrm{RF}$ & Regional Forces \\
\hline PSDF & Peoples Self Defense Forces \\
\hline PRT & Provincial Reconstruction Team \\
\hline RVN & Republic of Vietnam (South Vietnam) \\
\hline SFAAT & Security Force Advisory and Assistance Teams \\
\hline SRO & Stability and Reconstruction Operation \\
\hline TCAPF & Tactical Conflict Assessment and Planning Framework \\
\hline UNAMA & United Nations Assistance Mission Afghanistan \\
\hline U.S. & United States \\
\hline U.S.C. & United States Code \\
\hline USG & United States Government \\
\hline USMC & United States Marine Corps \\
\hline VC & Viet Cong \\
\hline VCI & Viet Cong Infrastructure \\
\hline VSO & Village Stability Operations \\
\hline WMD & Weapons of Mass Destruction \\
\hline
\end{tabular}




\section{ILLUSTRATIONS}

Page

Figure 1. DOS Adaptation from a Peacetime to a Wartime Environment. .....................................4

Figure 2. Comparative Timelines of Military-Led to Balanced Political-Military Approaches. ...37 
As we look beyond the wars in Iraq and Afghanistan -- and the end of long-term nation-building with large military footprints -- we'll be able to ensure our security with smaller traditional ground forces. ${ }^{1}$

- Barack Obama

\section{INTRODUCTION}

The President's remarks echo the collective feeling of a nation exhausted and frustrated with the result of a decade of attempted nation building in the Middle East. The same remarks could have been uttered by Richard Nixon four decades earlier as the nation extricated itself from the Far East. The President's assurance of the “end of long-term nation-building with large military footprints” is wishful thinking, but not a certainty. The withdrawal from Iraq and Afghanistan will likely put an end to these operations in the near term, but the future likelihood of America conducting nation building, or stability operations, in a friendly or allied nation can never be ruled out because their unpredictability typically stems from environmental conditions that are foisted upon national policymakers. Stability operations are rarely intentionally conducted, but are reactionary in nature. The last half century demonstrates that America appears to unwittingly find itself enmeshed in stability operations after an escalation of unfortunate events propels the nation into a stability operation it did not anticipate. The nation appears to avoid stability operations because they are extremely complex endeavors and end with mixed results. Despite active avoidance of stability operations, they were invariably conducted over the last four decades and will likely to be an element of decisive action in the future.

Stability operations seek to "reestablish a safe and secure environment, provide essential governmental services, emergency infrastructure reconstruction and humanitarian relief.”²

\footnotetext{
${ }^{1}$ Barack Obama, "Remarks by the President on the Defense Strategic Review,” The Pentagon. January 5, 2012, http://www.whitehouse.gov/the-press-office/2012/01/05/remarkspresident-defense-strategic-review (accessed Noveber 27, 2013).

${ }^{2}$ Joint Chiefs of Staff, Joint Publication 3-07, Stability Operations (Washington, DC: CreateSpace Independent Publishing Platform, September 29, 2011), vii.
} 
Stability operations require interagency cooperation between the Department of Defense (DOD) and the Department of State (DOS) to produce a balanced and synchronized unity of effort to achieve the nation's strategic aims. Although not all stability operations may involve the use of lethal force, the operational environments where stability operations occur typically have a high potential to devolve into violence. In Vietnam, Afghanistan, and Iraq counterinsurgency was a strategic approach used in conjunction with stability operations. Counterinsurgency includes “military, paramilitary, political, economic, psychological, and civic actions taken by a government to defeat an insurgency.”3 The U.S. Army’s Army Doctrine Publication ADP 3-0 Unified Land Operations recognizes the three elements of Decisive Action as a fluid mixture offense, defense and stability tasks, which gives the Army the agility to transition quickly from a stability task, like supporting governance, to offensive tasks like destroying an insurgent force.

The transition from peaceful actions to lethal force is complicated for the military, but the military mitigates this because it is trained, organized and equipped to operate in a warzone. The nature of the warfare, whether it is traditional or irregular, may differ but ultimately it is still war. The DOS, however, has difficulty operating in a wartime environment because it is outside of its organizational comfort zone. The DOS conducts diplomacy, not war. Military cooperation with the DOS will become increasingly important because according to Joint Publication 3-07: Stability Operations, the DOS “is charged with responsibility for leading a whole-of-government approach to stabilization that includes the array of United States Government (USG) departments and agencies, including DOD and component Services and agencies." ${ }^{4}$ Understanding the DOS and their adaptation to the wartime environment is important for the U.S. Army professional in

\footnotetext{
${ }^{3}$ Joint Chiefs of Staff, 1-02 Department of Defense Dictionary of Military and Associated Terms (Washington, DC: CreateSpace Independent Publishing Platform, August 15, 2012), 54.

${ }^{4}$ Joint Chiefs of Staff, JP 3-07, viii.
} 
order to achieve cooperation and unity of effort with interagency partners (see Figure 1). Interagency cooperation during stability operations involving irregular warfare is easily understood in theory, but difficult to achieve in practice because of the differences between the DOD and the DOS.

Interagency differences were identified in Vietnam but many hard learned lessons were forgotten and then painfully relearned in Afghanistan and Iraq more than thirty years later. It is the responsibility of interagency professionals to capture and retain lessons from the last decade to ensure the next interagency operation does not lose precious time, money and people from relearning for a third time what had been established in Vietnam, Afghanistan and Iraq. This paper's audience is the U.S. Army's general purpose force in particular and the USG's executive agencies in general. Its purpose is to assist U.S. Army leaders in understanding the DOS organizational evolution when participating in an irregular warfare environment where there is a large military contribution. The problem this paper addresses is how to achieve USG interagency unity of effort by understanding the DOS contribution to the effort. This paper begins with the assertion that the DOS operates in a peace-time mindset and must undergo organizational change when pushed into an irregular wartime environment. The DOS is forced to adapt to environmental pressures in order to be successful. Once it leaves that wartime environment it returns to its normal peacetime organizational culture. 


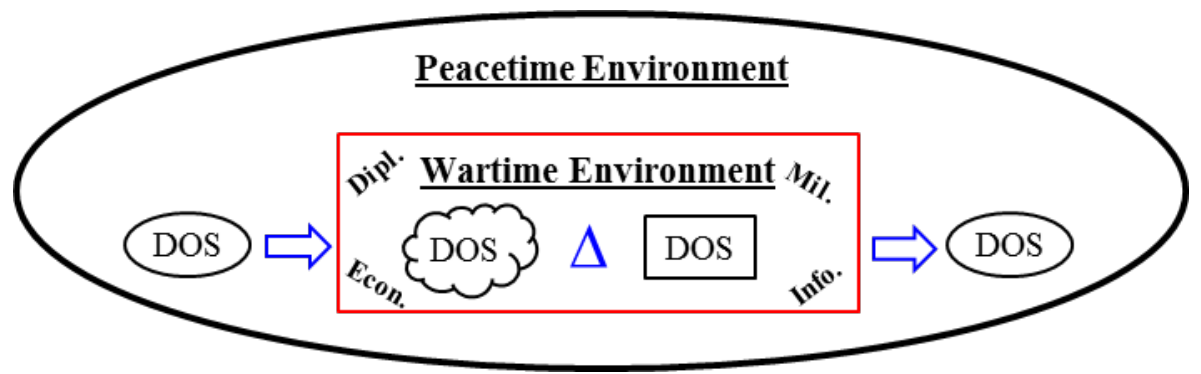

Figure 1. DOS Adaptation from a Peacetime to a Wartime Environment.

Source: Created by author.

$\underline{\text { In an analysis of DOS efforts in Vietnam, Afghanistan and Iraq three general trends }}$ emerge in the DOS adaption to an irregular conflict where there is a major military presence: (1) creation of ad hoc organizations, (2) a unified command structure with the DOD and (3) use of host nation solutions to solve local problems along with tools to measure their success. This paper is organized into four sections. The first section demonstrates why interagency difficulty exists between the DOS and DOD due to differences in purpose, organizational culture, and historic interaction. Section two delves into two case studies, Vietnam and then Afghanistan and Iraq, to orient the reader on the three general trends that are shared between case studies in the DOS evolution process. Section three combines the observations from the two case studies and uses history and theory as a basis for explaining the relevant outcomes from those cases. The concluding section recaptures the main points of the paper and addresses why this paper is relevant for future U.S. Army professionals.

\section{Two Organizational Cultures}

Unity of effort is difficult to achieve between the DOS and the DOD because of their differences in purpose (decisive vs continuous), organizational culture (formal vs informal) and historic interaction (peace vs war). The differences in purpose can be traced to their Constitutional origins. Simply put, the DOD is responsible for winning the nation's wars and the 
DOS is responsible for the nation's foreign affairs diplomacy. ${ }^{5}$ The Code of Laws of the United States of America, or U.S.C., clearly defines the purpose of the DOD, but gives little clarity to the purpose of the DOS. Divided into 51 titles, the U.S.C. codifies the DOD in Title 10-Armed Forces, and the DOS under Title 22-Foreign Relations and Intercourse. According to U.S.C. Title 10, the "primary purpose of the armed forces is to prepare for and to prevail in combat should the need arise.” ${ }^{6}$ The purpose for the DOD fits nicely into the Western tradition of warfare according to Victor Davis Hanson. In his book The Western Way of War: Infantry Battle in Classical Greece Hanson argues that the Western tradition of warfare is the decedent of classical Greek warfare where city-states used military forces to achieve quick, decisive outcomes to settle political disputes quickly to return to normal life as swiftly as possible. ${ }^{7}$ As a decedent of the Western military tradition, American military culture seeks quick, decisive wars and it mostly trains, equips and organizes its forces to achieve that goal. This purpose gives the DOD a decisive nature.

For the DOS, however, Chapter 1 of Title 22, “Diplomatic and Consular Services Generally,” is mostly repealed or omitted. In fact, it is very difficult to find a formal description for the official purpose of the DOS in the Constitution. This allows considerable latitude to interpret the role of the DOS for the President and the department itself. Informally, the department's purpose is to serve as the nation's “official channel through which the American

\footnotetext{
${ }^{5}$ Gaillard Hunt, "History of the State Department," The American Journal of International Law 3, no. 1 (January 1909): 162.

${ }^{6}$ Title 10-Armed Forces, 340, http://www.gpo.gov/fdsys/pkg/USCODE-2010title10/pdf/USCODE-2010-title10-subtitleA-partII-chap37-sec654.pdf (accessed Noveber 27, 2013).

${ }^{7}$ Victor Davis Hanson, The Western Way of War: Infantry Battle in Classical Greece (Berkeley: University of California Press, 2000), xxvi.
} 
people conduct their relations with other governments and peoples of the world."8 The ambiguous definition for the department's purpose is necessary because diplomacy cannot be decisive, but interminable. Diplomats navigate the complex world of international politics, attempting to steer the nation around dangers and embrace opportunities in line with the nation's norms and stated policies. In paraphrasing Everett Carl Dolman's definition of a strategist in Pure Strategy: Power and Principles in the Space and Information Age, one can describe a diplomat as someone who seeks "not culmination but a favorable continuation of events." 9 The DOS achieves its purpose through a never-ending endeavor to provide the United States with a "continuing advantage” relative to the other actors in the international community. ${ }^{10}$ The differences in purpose between the DOD and the DOS creates a decisive nature for the DOD contrasted against a continuous nature for the DOS.

The interagency unity of effort is further complicated because of organizational culture differences between the DOS and the DOD. Specifically, differences in education and decisionmaking create a formal organizational culture for the DOD and an informal organizational culture for the DOS. In his 1998 U.S. Army War College paper "Defense is From Mars, State is From Venus” Colonel Rickey Rife contrasts DOS and DOD cultures as if the two agencies come from completely different planets. He states that the organizational cultures create different character traits and decision-making philosophies producing "two cultures [that] are as alien as life forms

\footnotetext{
${ }^{8}$ John Upton Terrell, The United States Department of State: A Story of Diplomats, Embassies, and Foreign Policy (New York: Meredith Press, 1968), 5.

${ }^{9}$ Everett Carl Dolman, Pure Strategy: Power and Principles in the Space and Information Age (New York: Routledge, 2005), 5.

${ }^{10}$ Ibid., 14.
} 
from two competing planets, the warriors from Mars and the diplomats from Venus." ${ }^{11}$ The chief differences between the DOD and the DOS are in professional education and decision making philosophies. The DOD has a formal approach to education and decision making. U.S. military doctrine is the objectified distillation of history and theory that is legitimated through military professionals and academics, serving as a guide to action. The U.S. military's professional education system infuses the latest doctrine into its officers and non-commissioned officers at virtually every rank to provide a common understanding for action across the military. Doctrine also provides formalized decision making philosophies in both descriptive and prescriptive methods for practitioners to follow as a guide.

In contrast, education for Foreign Service Officers (FSO) in the DOS involves a seven week block of instruction at the Foreign Service Institute and then FSOs are largely left on their own for self-development and mentorship in the field. The agile nature of its organizational culture allows the DOS to be engaged simultaneously around the world with every nationality, ideology, religion, race and ethnic group to advance American foreign policy. Its agile organizational culture prevents it from being hindered by a rigid, centralized doctrine that may not be applicable around the world and in infinite situations. The DOS speaks a common jargon and observes approved methods of conduct, but these appear to be informal practices that are learned on the job. This makes the agency difficult to penetrate and understand by outsiders. Located in an area in the capitol prone to misty conditions, the DOS's informal nature gives an appropriate double entendre to their nickname "Foggy Bottom.” The differences in education and decision making provide another contrast between the formal nature of the DOD and the informal nature of the DOS.

\footnotetext{
${ }^{11}$ Ricky L. Rife, "Defense is From Mars, State is From Venus,” U.S. Army War College, Carlisle, PA, 1998.
} 


\section{$\underline{\text { Historic Interaction }}$}

Historic interaction contributes to difficulties in DOD and DOS interagency unity of effort because the two departments operated largely exclusive of one another throughout the nation's history. The two departments exercised a dichotomous approach to war and peace; the DOS reigned during peace and the DOD ruled during war. In 1939, Bertram Hulen captured this mindset in his book Inside the Department of State, writing "In war the Department of State necessarily is subordinate to the armed services. Ordinarily, in time of peace, it exercises full sway...”12 In a perfect situation, the DOS reigned supreme during peace, conducting its diplomatic role of supporting U.S. foreign policy. When political discourse with an international political actor hit an impasse, the U.S. military was often called upon as the lead U.S. agency and used force to achieve the desired objective. Once hostilities ended the DOS reasserted itself as the dominant U.S. foreign affairs agency. Diplomats did not completely disappear when the nation went to war, but busied themselves shaping strategic level policy with neutral nations and trying to maintain normalcy with non-belligerent states.

The DOS remained at the strategic level throughout most of the nation's wartime experience and even then major wartime policy decisions involved the president and his military advisors. A notable exception to this occurred during the Mexican-American War when President James K. Polk, who was highly distrustful of potential Whig presidential candidate General Winfield Scott, sent the diplomat Nicholas P. Trist to conclude the peace treaty with Mexico. Trist was co-opted by Scott and the resultant Treaty of Guadalupe Hidalgo was more in line with the desired resolution of the military than the DOS. ${ }^{13}$ For over a century this was the only

\footnotetext{
${ }^{12}$ Bertram Hulen, Inside the Department of State (New York: Whittlesey House, 1939), 251.

${ }^{13}$ Graham H. Stuart, The Department of State: A History of Its Organization, Procedure and Personnel (New York: Macmillan, 1949), 107.
} 
example of the DOS's wartime involvement in the theater of operations.

The Mexican-American War set precedence for military-mediated conflict resolution. In The Department of State: A History of Its Organization, Procedure and Personnel Graham H. Stuart notes that in the First World War, "Due to the overwhelming pressures of wartime activities, the DOS was not staffed to make plans for the peace treaty [Treaty of Versailles] which would end hostilities." ${ }^{14}$ At end the Second World War, Stuart notes that the "State Department, it must be conceded, did not play a very important role in the Yalta Conference.” ${ }^{15}$ An interesting development during World War II, however, was the establishment of the DOS’s Office of Foreign Relief and Rehabilitation Operations (OFFRO) on November 21, 1942. The OFFRO was headed by former New York Governor Herbert Lehman and tasked to “move in behind the front line in Europe to provide relief to newly liberated peoples” in the form of food, agricultural and economic aid. Lehman stated his purpose was to "help people to help themselves" and he was adamant that his operation was not simply to direct aid, but "assisting war-stricken peoples in reviving their own production of essential goods and services as rapidly as possible.”16 Ultimately, Lehman's operations were subordinate to the military commander responsible for occupation duties.

The War Department's duties from the founding of the nation to the mid- $20^{\text {th }}$ Century complimented the DOS approach to war. The challenge of irregular warfare was mitigated during this timeframe due to the lack of global communications and the nature of the U.S. military.

\footnotetext{
${ }^{14}$ Stuart, The Department of State: A History of Its Organization, Procedure and Personnel, 246.

${ }^{15}$ Ibid., 415.

${ }^{16}$ Herbert Lehman, “Address Given by Herbert H. Lehman” (lecture, Office of Foreign Relief and Rehabilitation Operations, Washington, DC, June 17, 1943), http://www.cvce.eu/ content/publication/2002/10/14/f71e490b-204a-405d-92d8-936a1b8150e0/publishable_en.pdf (accessed January 28, 2014).
} 
Modern insurgents can find psychological support for their cause utilizing modern technology such as the internet as well as communication devices that allow them to project their message and to shape their strategic narrative. The improved physical communication and transportation networks of roads, airports and seaports combined with more numerous and faster cars, planes and ships provide an insurgent with personnel and materials from abroad at a much faster rate than before. More importantly, the U.S. military’s “peacetime” role before the mid-20 ${ }^{\text {th }}$ Century was a constabulary force, serving on the Indian frontier or against domestic uprisings. Although not doctrinally stated, this informal role of the U.S. Army provided it with seasoned veterans and commanders who knew how to conduct counterinsurgency. During the Philippine Insurrection in 1899 for example, Brigadier General Samuel B.M. Young was responsible for the insurgentinfested $1^{\text {st }}$ District in Northern Luzon Province. Using experience he garnered from his years on campaign pacifying the American West, Young implemented many counterinsurgency principles recognized today such as increased intelligence networks, decentralized military operations and improved civilian infrastructure to support the U.S.-backed government in Manila. ${ }^{17}$ During this period the military was comfortable performing military governorship, establishing occupational governments in the Philippines, the Dominican Republic, Puerto Rico and Cuba.

The closure of the American frontier at the end of the $19^{\text {th }}$ Century, and the industrial wars of the $20^{\text {th }}$ Century, forced the military to abandon its constabulary mission and focus on developing a large professional, technically-oriented force that was trained, equipped and organized to fight a European-style battle of annihilation against a Cold War Soviet adversary. In a generation the military seemingly forgot how to control populations and support civil governments in favor of learning how best to destroy the enemy. Military historians like Russell

${ }^{17}$ Robert D. Ramsey III, Savage Wars of Peace: Case Studies of Pacification in the Philippines, 1900-1902: The Long War Series Occasional Paper 24 (Leavenworth, KS: Combat Studies Institute Press, 2012), 45-50. 
Weigley who wrote The American Way of War: A History of U.S. Military Strategy and Policy appeared to vindicate America's shift in warfare, noting America's military preference to deliver a devastating military victory over its armed adversaries through attrition or annihilation. ${ }^{18}$ Since the U.S. Army made this shift, it has struggled to regain its ability to execute irregular warfare unilaterally. The understanding of DOS rule during general peace and DOD rule during general war fell apart in the mid-20 ${ }^{\text {th }}$ Century with the rise of irregular warfare. Irregular warfare, often employing insurgency, operates somewhere in the middle of the spectrum of general peace and general war. Due to irregular warfare's nature of straddling the boundaries of peace and war, the DOD and DOS are required to operate together to conduct counterinsurgency and successful stability operations.

\section{Two Types of Warfare}

The U.S. military identifies the two basic types of warfare as traditional and irregular warfare. ${ }^{19}$ Joint Publication 1: Doctrine of the Armed Forces of the United States defines traditional warfare as "a violent struggle for domination between nation-states or coalitions and alliances of nation states...[involving] force-on-force military operations in which one adversary employs a variety of conventional forces and special forces against each other in all physical domains...”20 The U.S. military excels at traditional warfare because it is more in line with the violent, decisive nature of the Western military tradition. In On War, Carl von Clausewitz describes these conflicts as more military in nature because the emotional intensity behind their

\footnotetext{
${ }^{18}$ Russell F. Weigley, The American Way of War: A History of United States Military Strategy and Policy (Bloomington: Indiana University Press, 1977), 5, 143.

${ }^{19}$ Joint Chiefs of Staff, Joint Publication 1 Doctrine for the Armed Forces of the United States (Washington, DC: CreateSpace Independent Publishing Platform, March 25, 2013), xii.

${ }^{20}$ Ibid., $\mathrm{x}$.
} 
political objectives leans toward unlimited war. ${ }^{21}$ In War From the Ground Up: Twenty-First Century Combat as Politics, Emile Simpson writes that the strategic audience, the ultimate decision-maker, in a traditional conflict tends to be the head of government. ${ }^{22}$ The head of state is more likely to be influenced through traditional military actions like the defeat of his military or occupation of his territory. Traditional warfare is well within the comfort zone of the military and permits separation of the DOD and the DOS.

Irregular warfare poses difficulties for both military leaders and diplomats. The military struggles because the DOS and DOD cannot be separated, but must operate together. The diplomats struggle because their organizational culture is not accustomed to operating within a warzone. Joint Publication 1-02: Department of Defense Dictionary of Associated and Military Terms defines irregular warfare as “a violent struggle among state and non-state actors for legitimacy and influence over the relevant population(s)." ${ }^{23}$ Clausewitz describes irregular conflicts as more political in nature because the emotional intensity behind their political objectives leans toward limited war. The strategic audience in an irregular conflict, according to Simpson, tends to be the general population. ${ }^{24}$ The military cannot lethally influence a general population and retain international legitimacy. Instead, the general population must be engaged politically, ideally through a U.S.-friendly host nation government. While the U.S. military still has a security role it is not particularly well suited to provide political support to friendly

\footnotetext{
${ }^{21}$ Carl von Clausewitz, On War, Edited and Translated by Michael Howard and Peter Paret (Princeton, NJ: Princeton University Press, 1984), 87.

${ }^{22}$ Emile Simpson, War from the Ground Up: Twenty-First Century Combat as Politics (New York: Columbia University Press, 2012), 27.

${ }^{23}$ Joint Chiefs of Staff, Joint Publication 1-02 Department of Defense Dictionary of Military and Associated Terms (Washington, DC: CreateSpace Independent Publishing Platform, 2012), 137.

${ }^{24}$ Simpson, War from the Ground Up: Twenty-First Century Combat as Politics, 27.
} 
governments. The DOS is the best instrument of national power to engage the political dimensions of irregular conflict because the ambassador serves as the President's personal representative and the managerial capacity of the DOS allows it to oversee other U.S. agencies that can contribute to the effort, providing the whole-of-government approach.

Although the DOS is tasked to lead the interagency effort in a counterinsurgency environment, it is still an irregular warzone and the DOS is not accustomed to operating within this environment. It must undergo organizational changes to adapt to its environment to be successful. The next section analyzes the three general trends of DOS evolution in an irregular environment against the two case studies of (1) Vietnam and (2) Afghanistan and Iraq.

\section{ANALYSIS}

\section{Vietnam}

In 1954 French colonialism ended in Indochina and the colony was separated into Laos, Cambodia, the Democratic Republic of Vietnam (DRV or North Vietnam) and the Republic of Vietnam (RVN or South Vietnam). The Cold War made the region a center of American and Soviet interest in the ideological struggle between democracy and communism. Vietnam appeared to share many of the same characteristics as South Korea, where the communist-backed north sought conquest of the non-communist south. Seeking to contain the spread of communism, the United States reluctantly supported the RVN against a DRV-sponsored insurgency. During the Eisenhower and Kennedy administrations the United States assisted RVN-led counterinsurgency operations with material and military advisors. The counterinsurgency effort, known as pacification, required a balanced political-military approach to be successful. Fearing for the survival of the RVN, the Johnson administration significantly increased the U.S. military presence and control of the war. The American approach to meeting the DRV threat from 19641966 resulted in an unbalanced militarization of the conflict that largely ignored the pacification 
dimension of the war. The U.S. military's forceful measures focused on enemy attrition and search and destroy tactics which were unsuited to winning the support of the population from the communists. Often the military’s traditional approach to war alienated the United States and the RVN from the population they were there to protect. The military headquarters in Vietnam, the Military Assistance Command, Vietnam (MACV), commanded by General William Westmoreland, executed the military portion seemingly in parallel instead of in tandem with the pacification effort. $^{25}$

In May 1967, almost two and a half years into the conflict, President Johnson appointed Ambassador Robert Komer to lead one central agency to oversee pacification, the Civil Operations and Revolutionary (later Rural) Development Support (CORDS) program. ${ }^{26}$ In addition to unifying all non-military USG agencies under one program, pacification became the responsibility of MACV and CORDS was subordinated under the military headquarters. This political-military unity of effort represented an important development between the DOS and DOD in the prosecution of the conflict in Vietnam. The DOS evolution highlights the three trends in the agency's adaptation to the counterinsurgency environment in Vietnam: (1) the creation of provisional organizations, (2) a unified command structure between the DOS and the DOD (3) and use of RVN solutions to solve South Vietnam's problems.

One trend illustrated in Vietnam was the creation of the ad hoc organization, CORDS. According to Komer, strategic policymakers at the highest levels understood the unique politicalmilitary sensitivity of Vietnam. Both Presidents Kennedy and Johnson recognized the political

\footnotetext{
${ }^{25}$ Robert Komer, Bureaucracy Does Its Thing: Institutional Constraints On US-GVN Performance in Vietnam (Santa Monica, CA: Defense Advanced Research Projects Agency, Rand Corporation, August 1972), 84.

${ }^{26}$ Andrew F. Krepinevich Jr., The Army and Vietnam (Baltimore, MD: Johns Hopkins University Press, 1988), 187.
} 
nature of the Vietnamese conflict and what sort of civil-military effort it would require. ${ }^{27}$ The war in Vietnam was an ideological struggle for American policymakers who envisioned the communist-inspired insurgency as an outgrowth of a worldwide communist movement emanating from Moscow. The DRV adversary targeted the RVN population to join the communists with seductive promises of national liberation and communist utopia. This required a continuous political counter-effort from the United States and its RVN ally to maintain "hearts and minds." A balanced political-military strategy was formulated in Washington D.C. with the military providing security and non-military agencies executing pacification. The actual execution in Vietnam was militarily heavy and disjointed politically. Komer blamed the disconnection between the formulation of strategy in Washington and its execution in Vietnam on the DOS's organizational resistance to change. Diplomats, particularly the ambassadors, did not execute their diplomatic duties in Vietnam differently than a country at peace. Besides the normal day-today diplomatic activities, the country team displayed very little interest in getting directly involved in the war effort and only challenged MACV on the topic of out-of-country military operations. ${ }^{28}$ If the military appeared content to fulfill its role attempting to fight decisive battles, then the country team was equally content to fall into its "institutional repertoire” of statecentered diplomacy and not executing its role as central manager of the pacification effort. ${ }^{29}$

According to Komer, the civilian agencies tended to "focus primarily on that with which they were most familiar." ${ }^{30}$ Not only did the country team shy away from MACV involvement, but other facets of its institutional culture, particularly its common practices, inhibited its

\footnotetext{
${ }^{27}$ Komer, Bureaucracy Does Its Thing, 1.

${ }^{28}$ Ibid., 34.

${ }^{29}$ Ibid., 61.

${ }^{30}$ Ibid., 60 .
} 
performance. The DOS’s “skewed incentive program” meant that the Vietnam warzone was a professional dead-end for ambitious FSOs who could advance their careers elsewhere. Much like their military counterparts, FSOs rotated through Vietnam in one year cycles. This created a lack of institutional memory within DOS in Vietnam, causing John Paul Vann to remark, “We don’t have twelve years' experience in Vietnam. We have one year's experience twelve times over.”31 Johnson specifically wanted the ambassador in Vietnam to take charge of the civil and military agencies in Vietnam to ensure American efforts were integrated and synchronized. Johnson placed this responsibility first on Henry Cabot Lodge and later Maxwell Taylor, but the ambassadors were unable to accomplish this task. The department's institutional inertia was eventually overcome through a unified command structure with MACV. ${ }^{32}$

A second pattern the DOS established in Vietnam was developing a unified command structure with MACV. There was no overall manager of the American pacification effort in Vietnam. There was no one commanding the efforts of all of the U.S. agencies or synchronizing their activities according to a common plan that achieved a unified political aim. This left agencies on their own to figure out how they would contribute to pacification. The Chief of Mission (COM), typically the ambassador, is responsible for the USG unity of effort, but ambassadors in Vietnam appeared reluctant to assert their authority and unify American actions. With no unified command structure from 1964 to 1967, the country team's adaptation to the environment was too gradual. ${ }^{33}$ Unifying U.S. efforts in Vietnam underwent a two-step organizational change process. First all of the U.S. civilian agencies conducting disparate pacification efforts were consolidated under one pacification program, CORDS. In the second

${ }^{31}$ Komer, Bureaucracy Does Its Thing, 67.

${ }^{32}$ Graham A. Cosmas, MACV: The Joint Command in the Years of Escalation, 1962-1967 (Washington, DC: Military Bookshop, 2011), 357.

${ }^{33}$ Komer, Bureaucracy Does Its Thing, 11. 
part CORDS was subordinated under MACV.

As head of the pacification program Komer quickly solved the problem related to agency roles and responsibilities. Through force of will, Komer overcame organizational inertia with his ability to brutishly cut through bureaucratic apathy, earning him the nickname "Blowtorch.” In an unprecedented and counterintuitive approach, Komer expanded civilian control of the war effort by lobbying Defense Secretary Robert McNamara and Secretary of State Dean Rusk to have Johnson subordinate the pacification program under MACV. As Deputy to the Commander, United States Military Assistance Command, Vietnam (COMUSMACV) for CORDS, or DepCORDS, Komer was able to implement political reforms in Vietnam to compete with the communists. As DepCORDS, all agencies involved in the pacification program, including the Agency for International Development (AID) and the Central Intelligence Agency (CIA), were subordinate to Komer. In an unprecedented move, a civilian came to command military forces since most of Komer's command comprised military personnel. ${ }^{34}$ Echelons below MACV mirrored the political-military command structure established by Westmoreland and Komer at the theater level. The country was divided into four military regions, each commanded by a U.S. Army corps commander. Each corps commander had a civilian deputy in charge of the pacification efforts within that corps' area. Within the four corps areas were the country's fortyfour provinces with a lead CORDS advisor who was either civilian or military depending on the security situation. ${ }^{35}$ Within each province were division CORDS cells who worked directly with hamlets and villages.

A third trend State displayed in Vietnam was the use of RVN solutions to solve the

${ }^{34}$ Richard A. Hunt, Pacification: the American Struggle for Vietnam's Hearts and Minds (Boulder: Westview Press, 1995), 90.

${ }^{35}$ James H. Willbanks, Abandoning Vietnam: How America Left and South Vietnam Lost Its War (Lawrence, KS: University Press of Kansas, 2004), 33. 
unique problems of South Vietnam. The initial pacification programs started by the RVN were rural security, rural development and refugee resettlement. These programs were conceived and implemented by President Ngo Dinh Diem and supported later by President Nguyen Van Thieu. These programs did not receive enough support to be effective due to mismanagement by the RVN and indifference by MACV. Using the RVN programs as a model, Komer implemented four CORDS-led innovations to bolster the pacification effort: rural security, rural development, refugee resettlement and the Hamlet Evaluation System (HES).

First, CORDS used RVN solutions by taking the lead on three security-oriented programs: indigenous security, the insurgent defection program and the anti-Viet Cong infrastructure campaign (VCI). Komer utilized these programs to train rural security known as the Regional Forces (RF) and Popular Forces (PF) and later as the Peoples Self Defense Forces (PSDF) in an attempt to provide protection to contested areas in the absence of MACV or ARVN forces. The RF/PF and PSDF were local militias, loyal to the RVN and trained by Mobile Advisory Teams (MAT) that were manned by MACV soldiers. CORDS headed the defection program, known as Chieu Hoi (Open Arms), to entice VC irregulars into the RVN ranks, which caused intelligence and psychological setbacks to the communist cause. Finally, the Phung Hoang (All-Seeing Bird) or Phoenix program was a GVN-initiated program that was invigorated by CORDS. Phoenix was part of the anti-VCI campaign designed to kill enemy leaders and disrupt insurgent operations.

Second, CORDS used the RVN approach to advance rural development. With security established by MACV and CORDS territorial security forces, CORDS-run rural development was spearheaded by the U.S. Army Corps of Engineers (USACE) and AID. Rural development activities included building local government capacities, improving local economies, building communications networks, agricultural reforms, public health to include medical-civic action 
programs (MEDCAPs), and expanding education opportunities. ${ }^{36}$

Third, CORDS reformed the disastrous GVN-led agrovilles program that in 1961 forced the resettlement of thousands of Vietnamese from their home villages in an attempt to deny the VC a source of rural support. CORDS worked to resettle those displaced by conflict, winning favor with the locals and denying a source of recruitment for the communists. Fourth, an important policy initiative CORDS administered was not RVN in origin, but was used to measure the effectiveness of RVN solutions. The Hamlet Evaluation System (HES), seemingly administrative in nature, was crucial to the pacification program. The HES evaluated six areas in a given region: (1) Viet Cong activity, (2) subversion and political activities, (3) defense and security capabilities of friendly forces, (4) administrative and political activities of the government, (5) health, education and welfare activities, (6) and economic development. ${ }^{37}$ These evaluations allowed leaders to measure pacification successes and failures that guided future efforts based on experiences.

Ultimately the United States failed in Vietnam. Lack of American domestic support led to withdrawal and the RVN's inability to stand on its own led to eventual collapse from continued attacks by the DRV. Komer places the blame first on RVN corruption and second on the U.S. bureaucracies' inability to adapt to the unprecedented environment. CORDS represented a significant evolution in the DOS approach to counterinsurgency. It demonstrated that in an insurgency where there is a major military presence, the DOS must create ad hoc organizations to overcome its institutional inertia, unify its command structure with the military and refine local solutions to solve local problems. State’s four main measures: rural security, development,

\footnotetext{
${ }^{36}$ Dinh Tho Tran, Pacification (Washington, DC: U.S. Army Center of Military History, 1980), 65.

${ }^{37}$ Hunt, Pacification: The American Struggle for Vietnam's Hearts and Minds, 95.
} 
refugee resettlement and the HES, tipped the scales in favor of the American and RVN between 1967 and 1971. Only after the war did North Vietnamese officials admit that pacification was one of the most feared weapon system in the U.S.-RVN arsenal. ${ }^{38}$ Other problems within the DOS remained unsolved like one year rotations and skewed incentive programs for FSOs. Although the DOS went through considerable adaptation in Vietnam, the institution appeared to jettison its lessons learned from the conflict after American involvement ended in the country. Much like the military which reoriented on the Soviet threat in central Europe, the DOS sought to wash itself of the defeat and lapse back into its bureaucratic comfort zone of state-centered diplomacy.

\section{The Interlude}

America's defeat in Vietnam resulted in a public disdain for nation building and protracted international conflict. Both the DOD and DOS appeared to drift apart from one another and revert to their traditional, state-centric routines. The remarkable commonality of the ensuing three decades is that when the military involved itself in a land campaign substantial involvement by the DOS was noticeably absent. Both entities seemed to have reverted to their informal understanding of DOS rule during peace and DOD predominance during war. The separation between the agencies following Vietnam remained rigid in the 1980s, became increasingly blurred in the 1990s, and finally collapsed in the new millennium.

The bombing of the U.S. Marine Corps barracks in Beirut, Lebanon in 1983, killing 241 American Service members, further intensified the nation's hostility towards irregular conflict and stability operations. However, this event was quickly overshadowed by the military coup in communist Grenada that led to a U.S. military seizure of the island. The Grenada campaign was a military-led operation that used overwhelming force to secure the military objectives in a four day

${ }^{38}$ U.S. Embassy Saigon, A Preliminary Report On Activities During the 1969 Autumn Campaign (Saigon: Vietnam Documents and Research Notes No. 82, July 1972), 3. 
campaign and then quickly relinquished the post-conflict operations to an international peacekeeping force comprised of neighboring Caribbean nations. ${ }^{39}$ The events in Beirut and Grenada reinforced the notion of the preferred method of American fighting; traditional warfare that avoided protracted irregular conflicts like Vietnam. This approach to armed conflict was codified in 1984 in what came to be known as the Weinberger Doctrine. ${ }^{40}$ The nation was either at war or peace, but nothing in between. Under the Weinberger Doctrine, DOD and DOS roles remained separated in the next two conflicts that resulted in resounding U.S. military and political victories. In 1989 the United States conducted Operation JUST CAUSE in Panama and in 19901991 Operation DESERT STORM in the Middle East. In both instances the wars were relatively short (six weeks in Panama and a nine month build up followed by a 100 hour ground campaign in the Middle East) and the local populations welcomed U.S. military forces as liberators. ${ }^{41}$ In both of these conflicts there was no need for protracted ground campaigns or counterinsurgencies. The DOD and DOS maintained their comfortable separation.

The end of the Cold War marked more, not less, American involvement in irregular conflicts. The last decade of the $20^{\text {th }}$ Century witnessed U.S. intervention in Somalia, Haiti, Bosnia and Kosovo. In each of these conflicts the U.S. military’s traditional approach struggled to cope with conflicts that were more political than military in nature. Killing enemy combatants,

\footnotetext{
${ }^{39}$ Mark Adkin, Urgent Fury: The Battle for Grenada: the Truth Behind the Largest U.S. Military Operation Since Vietnam (London: Trans-Atlantic Publications Inc, 1989), 219.

${ }^{40}$ Caspar Weinberger, “The Uses of Military Power” (lecture, The National Press Club, Washington, D.C., November 28, 1984), http://www.pbs.org/wgbh/pages/frontline/shows/military/force/weinberger.html (accessed December 16, 2013).

${ }^{41}$ R. Cody Phillips, Operation Just Cause: The Incursion Into Panama (Washington, DC: The U.S. Army Center for Military History, 2012), 42, http://www.history.army.mil/brochures/Just\%20Cause/JustCause.htm, (accessed December 16, 2013); Nasir Al-Sabah, audio conference with Various Reporters, Washington, DC, February 28, 1991, http://bushlibrary.tamu.edu/research/public_papers.php?id=2750\&year=1991\&month=2, (accessed January 28, 2014); Adkin, Urgent Fury, 318.
} 
seizing terrain and destroying infrastructure proved futile and even counterproductive. These conflicts witnessed a steady increase of DOS involvement and interagency cooperation.

Fortunately the United States was not alone in these conflicts, but worked as part of a United Nations (UN) or a North Atlantic Treaty Organization (NATO) coalition where most member nations contributed government agencies and military peacekeepers trained for interagency stability operations. Further strain was alleviated through numerous intergovernmental organizations and nongovernment organizations that provided resources and know-how. Observing the strenuous relationship between the DOS and DOD during these operations, President Bill Clinton signed Presidential Decision Directive (PDD) 56 on May 1997, titled “Managing Complex Contingency Operations.” This directive stated:

While agencies of government have developed independent capacities to respond to complex emergencies, military and civilian agencies should operate in a synchronized manner through effective interagency management and the use of special mechanisms to coordinate agency efforts. Integrated planning and effective management of agency operations early on in an operation can avoid delays, reduce pressure on the military to expand its involvement in unplanned ways, and create unity of effort within an operation that is essential for success of the mission. ${ }^{42}$

In PDD-56, Clinton sought to establish comprehensive interagency reform. The decision offered interagency planning and decision making in "complex contingency operations” with a common unity of command in the form of an Executive Committee (ExCom), which was designed to yield unity of effort, concept of operations, rehearsals and training.

The "Vietnam Syndrome” still appeared to guide the American public and governmental institutions’ distaste for irregular conflict. The civil-military apparatus seemed to breathe a collective sigh of relief when presidential candidate George W. Bush, in criticism of Clinton’s worldwide peacekeeping missions, announced in a campaign speech at the Citadel on September

\footnotetext{
${ }^{42}$ The White House, "PDD/NSC 56: The Clinton Administration's Policy On Managing Complex Contingency Operations,” Presidential Decision Directives - PDD, https://www.fas.org/irp/offdocs/pdd56.htm (accessed December 16, 2013).
} 
23, 1999 that:

The problem comes with open-ended deployments and unclear military missions. In these cases we will ask, "What is our goal, can it be met, and when do we leave?” As I've said before, I will work hard to find political solutions that allow an orderly and timely withdrawal from places like Kosovo and Bosnia. We will encourage our allies to take a broader role. We will not be hasty. But we will not be permanent peacekeepers, dividing warring parties. This is not our strength or our calling. ${ }^{43}$

In an ironic turn of events, the president who vowed an end to open-ended military commitments to protracted irregular conflicts would end up presiding over the longest war in American history involving two herculean irregular conflicts that would once again press the DOS and DOD together.

\section{Afghanistan and Iraq}

On September 11, 2001 America awakened from its domestic tranquility with the terrorist attacks in New York City and Washington D.C. by Islamic fundamentalists. The attacks were perpetrated by the Al Qaida terrorist group led by Osama bin Laden who was taking refuge in Taliban-controlled Afghanistan. When the Taliban refused to surrender bin Laden the United States overran the country with the objective to kill or capture bin Laden and overthrow the supportive fundamentalist regime. The terrorist attack caused two shifts in Bush’s approach to international relations: nation-building and preemptive attack. First, Bush believed that the failed government conditions in Afghanistan that allowed Al Qaida to take root and flourish were to blame for the attacks. Second, his preemptive attack policy afforded an opportunity for the United States to attack terrorists and their sponsors before another catastrophic terrorist event

${ }^{43}$ George W. Bush, “A Period of Consequences,” (lecture, The Citadel, Charleston, SC, September 23, 1999), http://www3.citadel.edu/pao/addresses/pres_bush.html, (accessed December 16, 2013). 
transpired. ${ }^{44}$ These policies, combined with concerns of a potential attack with weapons of mass destruction (WMD) and idealistic notions of a democratic Middle East, led to the operation that aimed toward the liberation of Iraq in March 2003. It did not take long in either campaign before insurgencies emerged to contest U.S. post-conflict nation-building efforts. The United States found itself embroiled in two simultaneous irregular conflicts requiring a political-military interagency approach. The DOS and DOD were once again forced to achieve unity of effort to achieve strategic aims. The DOS repeated the same trends of adapting to the environment in Afghanistan and Iraq that it did in Vietnam: (1) the creation of provisional organizations; (2) a unified command structure between DOS and the military; and (3) the use of host nation solutions to solve local problems.

First, the DOS reacted to the environment in Operation ENDURING FREEDOM (OEF) and Operation IRAQI FREEDOM (OIF) by creating new structures to cope with the challenges the campaigns presented. This was significant in two areas; theater level organizational structure and common practices at the tactical level. The DOS organizational structures at the theater level were characterized by a gradual evolutionary process. Once these structures were in place, momentum gathered quickly at the tactical level. In Afghanistan the post-conflict reconstruction effort was subordinated beneath the multinational NATO’s International Security Assistance Force (ISAF) command as part of the Afghan National Development Strategy (ANDS). ${ }^{45}$ In early 2002 U.S. Army Civil Affairs teams fielded the Coalition Humanitarian Liaison Cells with "the task to assess humanitarian needs, implement small-scale reconstruction projects, and establish

\footnotetext{
${ }^{44}$ Executive Office of The President of the United States, The National Security Strategy of the United States of America: September 2002 (Washington, DC: CreateSpace Independent Publishing Platform, 2012), 15.

${ }^{45}$ Center for Army Lessons Learned, The Afghanistan Provincial Reconstruction Team Handbook: Observations, Insights, and Lessons (Leavenworth, KS: Center for Army Lessons Learned, February 2011), 15.
} 
relations with the UN Assistance Mission in Afghanistan (UNAMA) and nongovernmental organizations already in the field.” ${ }^{46}$ Though initiated by the U.S. Army, the DOS embraced the Provincial Reconstruction Team (PRT) concept within the same year and developed the organization. The PRTs were comprised of cross-functional members from the DOS, the military, other interagency partners and host nation linguists and cultural advisors. The skillsets of PRT members reflected the circumstances of the area they were assigned. Their purpose was to expand the role of the USG through enhancing control of the host nation government by strengthening local government, reconstruction and promoting self-sufficiency. ${ }^{47}$ PRTs supported a balanced unity of effort to the conflict by providing the political dimension of population engagement to complement the military’s security mission. PRTs were assigned to the provincial level in Afghanistan and Iraq but increased mobility and communications permitted them to support the numerous districts within the provinces they were assigned.

President Bush realized the United States needed a more balanced interagency approach to the conflict and in July 2004 the DOS created the State/Coordinator for Reconstruction and Stabilization (S/CRS). The S/CRS was charged with leading a 'whole-of-government' approach to stabilization and reconstruction operations (SRO). In December 2005 President Bush signed the National Security Presidential Directive 44, Management of Interagency Efforts Concerning Reconstruction and Stabilization. This directive moved planning and implementation of SROs to the control of the DOS. With the responsibility for reconstruction in Afghanistan, the DOS created the PRT Executive Steering Committee (ESC) at the theater level to provide "guidance

\footnotetext{
${ }^{46}$ Robert M. Perito "The U.S. Experience with Provincial Reconstruction Teams in Afghanistan: Lessons Learned,” United State Institute of Peace: Special Report, October 2005, 2, http://www.usip.org/sites/default/files/sr152.pdf, (accessed December 18, 2013).

${ }^{47}$ Steven Mains, PRT Playbook: Tactics, Techniques, and Procedures (Leavenworth, KS: CreateSpace Independent Publishing Platform, 2013), 2.
} 
for and oversight of all existing and proposed PRTs” in Afghanistan. ${ }^{48}$ In 2009 under the Obama administration’s “Way Forward” policy created the Office of Interagency Provincial Affairs (IPA) to "provide strategy and policy guidance on sub-national governance, stabilization issues, Afghan capacity-building programs and civil-military integration." ${ }^{49}$ The IPA is also responsible for administrative and logistic support to PRTs across Afghanistan.

In Iraq, the DOS organizational structure underwent similar modifications as it adapted to the counterinsurgency environment. The DOS participation evolved from a virtual non-existence to securing a dominant position in the reconstruction of the country. DOS's preeminent position in reconstruction proved decisive in neutralizing the insurgency, building up the Iraqi government and ultimately allowing the withdrawal of U.S. military forces. The department's increased role in the counterinsurgency took years to develop. In January 2003 President Bush signed National Security Presidential Directive 24, Post-War Iraq Reconstruction, making the DOD solely responsible for post-war reconstruction. Supposedly at the behest of Secretary of Defense Donald Rumsfeld, this measure undid any sort of interagency coordination process that had been achieved up to that point and gave the DOS neither incentive nor mandate to assist in post-

\footnotetext{
${ }^{48}$ Center for Army Lessons Learned, The Afghanistan Provincial Reconstruction Team Handbook: Observations, Insights, and Lessons (Leavenworth, KS: Center for Army Lessons Learned, February 2011), 33, http://usacac.army.mil/cac2/call/docs/11-16/11-16.pdf (accessed August 10, 2013); Center For Army Lessons Learned, The Iraq Provincial Reconstruction Team Handbook: Observations, Insights, and Lessons (Leavenworth, KS: Center for Army Lessons Learned, November 2010), http://usacac.army.mil/cac2/call/docs/11-03/11-03.pdf (accessed August 10, 2013); Joeseph Christoff, Provincial Reconstruction Teams in Afghanistan and Iraq (Washington D.C.: Government Accountability Office, 2008), http://www.gao.gov/new.items/d0986r.pdf, (accessed February 5, 2014).

${ }^{49}$ Center for Army Lessons Learned, The Afghanistan Provincial Reconstruction Team Handbook: Observations, Insights, and Lessons, 35.
} 
conflict planning. ${ }^{50}$ NSPD 24 also created the Office of Reconstruction and Humanitarian Assistance (ORHA); an organization whose exclusive mission was to plan and execute post-war reconstruction. The intent of this organization was never fully realized and six weeks after the invasion it was terminated and its mission was taken over by the Coalition Provisional Authority (CPA).

A year into OIF the conditions in the country slid from bad to worse as the insurgency increased in violence and scale. In May 2004 President Bush signed National Security Presidential Directive 36, United States Government Operations in Iraq. In this directive all reconstruction and relief operations were transferred to DOS control under the command of the COM. It also created two additional organizations; the Iraq Reconstruction Management Office (IRMO) under the control of the country team which was to "facilitate the transitioning of Iraq," and the Project and Contracting Office (PCO) which was a DOD-led organization charged with contract acquisition and project management support. ${ }^{51}$ Gradually, the DOS inserted itself more and more into the relief and reconstruction of Iraq. It borrowed many of the same concepts it was using in Afghanistan such as the State Embedded Team, precursor to the PRT. ${ }^{52}$ In October 2005 the DOS created the National Coordination Team (NCT) and formally introduced the PRTs in Iraq. ${ }^{53}$ In this operational framework the DOD presided over the budget through the IRMO and

\footnotetext{
${ }^{50}$ Special Inspector General for Iraq Reconstruction, Applying Iraq's Hard Lessons to the Reform of Stabilization and Reconstruction Operations (SIGIR, February 2010), 5, http://www.sigir.mil/files/USOCO/ApplyingHardLessons.pdf (accessed November 10, 2013).

${ }^{51}$ Special Inspector General for Iraq Reconstruction, Applying Iraq's Hard Lessons to the Reform of Stabilization and Reconstruction Operations, 6.

${ }^{52}$ United States Institute of Peace Association for Diplomatic Studies and Training Interview \#56, interviewed by W. Haven North, August 28, 2008.

${ }^{53}$ United States Institute of Peace Association for Diplomatic Studies and Training Interview \#3, interviewed by W. Haven North, February 21, 2008.
} 
the DOS directed the reconstruction effort through the NCT. The DOS created another organization in 2005, the Provincial Reconstruction Development Committee (PRDC) which served as a combined organization with DOS and Iraqi provincial officials to determine planning and prioritization of reconstruction efforts. ${ }^{54}$

Despite the DOS's ability to form provisional organizations to deal with the environment, it struggled to adapt its common practices in both campaigns. The DOS appeared less dynamic in adjusting individual standards and practices than their ability to create ad hoc organizations. One problem PRT personnel complained about was the lack of a debriefing process at the end of a tour to capture valuable lessons learned. ${ }^{55} \mathrm{~A}$ frustrated DOS contractor remarked "we have no

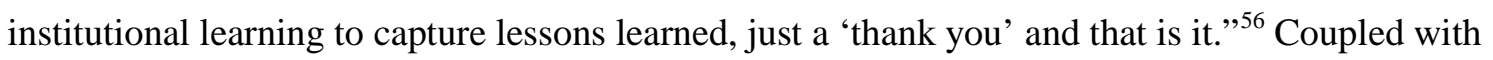
no formal lessons learned process was the additional problem of the short length of tours. Many personnel served between four to twelve months in a given area not including vacations. A FSO assigned to Khowst province in Afghanistan noted that "the shortness of tours of duty has been a problem for both civilian and military personnel, since it takes time to build experience and expertise.”57 A U.S. Army colonel assigned as deputy to Saladin PRT remarked, “tours of duty are too short-one year is not enough; extremely difficult in getting into and out of the area for

\footnotetext{
${ }^{54}$ United States Institute of Peace Association for Diplomatic Studies and Training Interview \#66, interviewed by Marilyn Greene, December 12, 2008.

${ }^{55}$ United States Institute of Peace Association for Diplomatic Studies and Training Interview \#14, interviewed by J. Zetkulic, October 19, 2004; United States Institute of Peace Association for Diplomatic Studies and Training Interview \#36, interviewed by W. Haven North, July 15, 2008.

${ }^{56}$ United States Institute of Peace Association for Diplomatic Studies and Training Interview \#63, interviewed by Mehmet Ali, September 21, 2008.

${ }^{57}$ United States Institute of Peace Association for Diplomatic Studies and Training Interview \#17, interviewed by Barbara Nielsen, May 1, 2005.
} 
short leaves-a disincentive to work in the area." 58 The disincentive to deploy to Afghanistan and Iraq also seemed to be another issue hindering the DOS and the interagency effort. A FSO working in the OPA remarked that all DOS personnel in Iraq volunteered for the assignment, demonstrating a skewed incentive program in the agency because it indicated an organizational culture where most people chose to work in matters that did not involve the nation being at war. ${ }^{59}$ A DOD employee working in the Ninawa PRT observed that DOS officials in the embassy in Baghdad “can’t just have senior people reporting to junior Foreign Service Officers and expect to have coherent programs.” ${ }^{60}$ Insufficient staff sizes and particularly pre-deployment training was inadequate in Iraq and Afghanistan for DOS personnel. Many PRT members cited that training with the unit they would be working with before deployment would have alleviated many of the problems encountered in theater as units and organizations are trying to get acquainted with so many aspects of their new surroundings. ${ }^{61}$

The second trend that manifested itself in Afghanistan and Iraq was the unified command structure between the DOS and DOD. In January 2007 President Bush announced his "New Way Forward” policy in Iraq. Led by General David Petraeus, an American counterinsurgency pioneer and commanding general of Multi-National Forces Iraq (MNF-I), the “New Way Forward” represented a new, interagency approach to the conflict. The operation called for drastically increasing the number of soldiers in the country in order to establish security, strengthen Iraqi

\footnotetext{
${ }^{58}$ United States Institute of Peace Association for Diplomatic Studies and Training Interview \#35, interviewed by W. Haven North, May 9, 2008.

${ }^{59}$ United States Institute of Peace Association for Diplomatic Studies and Training Interview \#66, interviewed by Marilyn Greene, December 12, 2008.

${ }^{60}$ United States Institute of Peace Association for Diplomatic Studies and Training Interview \#55, interviewed by Marilyn Greene, August 6, 2008.

${ }^{61}$ United States Institute of Peace Association for Diplomatic Studies and Training Interview \#38, interviewed by Sam Weston, June 18, 2008.
} 
security forces through military-led partnership and training, appease disenfranchised Sunni elements of society through the Sons of Iraq militia program and most importantly, build Iraqi capacity in the areas of governance, rule of law, economics and infrastructure through the PRTs. The PRTs were expanded and partnered with U.S. Army brigades and U.S. Marine Corps regiments called embedded PRTs (ePRTs). Although no formal command authority existed between both entities, they successfully achieved unity of effort through personal interaction and internal relationship building. A similar surge occurred in Afghanistan in 2009 under the Obama administration’s “Way Forward” policy with General Stanley McChrystal and Ambassador Karl Eikenberry (recently retired U.S. Army Lieutenant General) where PRT efforts were reinvigorated under their leadership. U.S. Special Forces elements working in conjunction with PRTs created village militias known as Afghan Local Police as part of the local stability method called Village Stability Operations (VSO). The villagers agreed to be trained and were on the government payroll, tying them to Kabul and receiving reconstruction assistance from the PRTs. In return, they provided security against insurgent forces who viewed them as the most serious threat in the country.

The role of the DOS was extended even further in 2008 under the Unified Common Plan between the COM and the military. Incoming units in some areas were instructed by the MNF-I commander, General Ray Odierno, that "in many areas, our primary efforts are focused on assisting PRTs to help provincial governments provide essential services and economic opportunities for their citizens.”62 In a manner very similar to Vietnam, the DOS gained more influence over the war effort and sway within the military through their close partnership. The turnaround of the security situation was immediate. The surge provided more troops to enhance security and allowed the PRTs to build Iraqi governance capacity, crippled the insurgents, and

62“'An Interview with Raymond T. Odierno”, Prism 1, no. 2 (March, 2010): 141-48, http://cco.dodlive.mil/files/2013/08/prism1-2.pdf, 143 (accessed December 18, 2013). 
removed neutral civilian support from the insurgents by enabling the Iraqi government to lead with substantive improvements to the Iraqi way of life. The partnerships of PRTs to military brigades and regiments ensured localized efforts were synchronized and appropriate to the given area of operations. This whole-of-government approach enhanced peace and security, setting into motion the inevitable drawdown and ultimate American withdrawal from Iraq.

The third reoccurring trend in Afghanistan and Iraq was the use of host nation solutions to solve local problems. At the height of both conflicts there were twenty-nine PRTs in Afghanistan and sixteen in Iraq. Each of these PRTs were staffed and focused according to the unique characteristics of the province or district it was assigned to support. For instance, in Babil, Iraq the PRT's main focus was agriculture while in Mosul it was textiles. The PRTs organized themselves according to five main lines of effort: infrastructure, health, planning, economics, and governance. Despite their name, the main role of the PRT was not reconstruction, but capacity building. Capacity building is the improvement of governmental, social and economic systems to achieve self-sufficiency from the coalition forces and successfully support the population. The PRTs did not govern, but enhanced the local government's ability to govern its own people. The DOS director for the NCT in Iraq stated it was the PRT goal to "let the Iraqis take the lead.”63. While the host nation's central government developed in the capital, the PRT's ability to extend to the lower levels of government allowed simultaneous governmental development at national, provincial and district levels instead of a slower, top-down process of sequential development.

The PRTs used several tools to measure its effectiveness in building partner capacity. The Interagency Conflict Assessment Framework (ICAF) was created in 2008 to “develop a commonly held understanding, across relevant USG Departments and Agencies of the dynamics

\footnotetext{
${ }^{63}$ United States Institute of Peace Association for Diplomatic Studies and Training Interview \#5, interviewed by Marilyn Green, March 12, 2008.
} 
driving and mitigating violent conflict within a country that informs U.S. policy and planning decisions.”64 The Tactical Conflict Assessment and Planning Framework (TCAPF) served as “a standardized diagnostic framework for tactically assessing the causes of Instability/Conflict in an Area of Operation." ${ }^{65}$ USAID uses the TCAPF as an iterative framework to plan and execute reconstruction operations. It is used to focus on stability and allows commanders to see, understand, measure and act in the area of operations. ${ }^{66}$ The third tool commonly used by USAID was the District Stability Framework (DSF) to target drivers of instability. The DSF was an assessment and planning tool to gather situational awareness, perform analysis, conceptual program design and evaluation. ${ }^{67}$ This tool was created specifically with civil-military relations in mind to guide counterinsurgency efforts.

\section{SYNTHESIS}

\section{Ad hoc Organizations}

The DOS relied on creating ad hoc organizations to meet the needs of the counterinsurgency environment. Whether intended or not, these organizations helped the DOS get past its organizational resistance to change and adapt to the environment. The CORDS program

\footnotetext{
${ }^{64}$ Office of the Coordinator for Reconstruction and Stabilization, Interagency Conflict Assessment Framework (ICAF) (Washington D.C.: United States Department of State, November 2010), http://www.state.gov/documents/organization/187786.pdf, 2 (accessed December 18, 2013).

${ }^{65}$ James Derleth, “The Tactical Conflict Assessment” (lecture, PPC Conference Room, January 5, 2009 http://pdf.usaid.gov/pdf_docs/PNADN621.pdf (accessed December 18, 2013).

${ }^{66}$ Office of Military Affairs (OMA), Tactical Conflict Assessment and Planning Framework (Washington D.C.: United States Agency of International Development, 2010), http://pdf.usaid.gov/pdf_docs/Pnadn621.pdf (accessed December 18, 2013).

${ }^{67}$ United States Agency for International Development, “The District Stability Framework,” USAID: From the American People, February 08, 2013, http://www.usaid.gov/work-usaid/partnership-opportunities/us-military/training/district-stabilityframework (accessed December 18, 2013).
} 
in Vietnam and the PRT in Afghanistan and Iraq were created in theater to meet the particular challenges those environments presented. Until 2004 with the creation of the S/CRS, the DOS did not have a command and control element to oversee SROs, relying instead on the COM or provisional organizations in theater. This differs from a military that operates under a doctrinal joint framework of hierarchical command structures that can be modularized and deployed anywhere in the world. The DOS's forward elements are its embassies, which were not created to conduct or lead counterinsurgency efforts and are ill-suited for the task when pressed to do so.

The State Department demonstrated that provisional organizations yield results because of their mission focused nature. These organizations, comprised of interagency and often multinational partners, force their members into a new setting where they are not so focused on their parent organizations’ processes and traditional ways of doing business. Culture is a powerful force. In Organizational Culture and Leadership Edgar Schein defines culture as "a pattern of shared basic assumptions learned by a group as it solved its problems of external adaptation and internal integration...to be taught to new members as the correct way to perceive, think, and feel in relation to those problems.”68 An organization’s cultural barriers are difficult to overcome, and therefore can act as an obstacle to effective adaptation. The DOS is not used to waging war because historically wars have been waged exclusively by the DOD. When the DOS enters a war it is submerged into something its organizational culture does not readily have a pre-programed answer for. The way the DOS copes with this new environment is through the creation of ad hoc groups.

Ad hoc groups take members of the organization away from their normal settings and put them in a new environment with new problems and new teammates. This prevents individuals

\footnotetext{
${ }^{68}$ Edgar H. Schein, Organizational Culture and Leadership, 4 ed. (San Francisco: JosseyBass, 2010), 18.
} 
from holding onto established customs and norms and facilitates problem solving because the individual is part of a new group dynamic which they must adapt to. In "Overcoming Resistance to Change” Lester Coch and John R.P. French noted that "resistance to change can be overcome if group participation is encouraged in planning for the change." ${ }^{69}$ When people are outside of their normal organization, they want to contribute positively to the new group which they are assigned. They resist establishing cultural or habitual barriers that exist in their typical organizations because they are in a new organization where those rules do not apply. This is supported by Robert R. Black and Jane S. Mouton’s assertion that organization-development “is premised upon the notion that any organization wishing to survive must, from time to time, divest itself of those parts or characteristics contributing to its malaise.”70

In "Organizations of the Future” written in 1967, the same year CORDS was established, Warren Bennis lambasts bureaucracy’s inability to change. He blames it on increased complexity and specialization between subcultures in a bureaucracy and differences between "philosophical values underlying managerial controls and behavior." ${ }^{\text {71 }}$ If this trend continues, the future will see even more disparity between the DOS and DOD than already exists. This prediction is supported in the two case studies. It took the USG longer to shift policy from a military focus a balanced focus in Afghanistan and Iraq (forty-six months and seventy months respectively) than it did in Vietnam (thirty-five months). Bennis' solution is for all organizations to be “temporary” or ad hoc. These will be “rapidly changing temporary systems” or ““task forces’ organized around problems-to-be-solved by groups of relative strangers who represent a diverse set of professional

${ }^{69}$ Walter E. Natemeyer and Jay S. Gilberg, Classics of Organizational Behavior, 2nd ed. (Danville, IL.: North American Training \& Development, 1989), 259.
${ }^{70}$ Ibid., 260.
${ }^{71}$ Ibid., 260. 
skills. The groups will be arranged on an organic rather than mechanical model; they will evolve in response to a problem rather than to programmed role expectations."72 Ad hoc organizations work because they are comprised of problem solvers, not agents forced to conform to the traditions, procedures and regularities that their typical structures require. The DOS appears to cope with a new environment through provisional organizations. To the casual observer this appears to be a knee-jerk reaction to the problem, but to the organizational theorist it demonstrates a clear-sighted, intellectual approach to problem-solving because the department must realize that locking itself into any structure, like the S/CRS, will ultimately come with bureaucracy's increased size, complexity and diminished ability to cope with unexpected change. CORDS in Vietnam and the PRTs in Afghanistan and Iraq demonstrated the power of ad hoc organizations. These cross-functional teams comprised of numerous USG agencies and multinational partners were better equipped to deal with the specific problems of their assigned area.

Ad hoc organizations were not able to overcome some of the department's organizational cultural common practices. Short tour length, disincentive to deploy to the war zone, poor predeployment training and building institutional memory for future conflicts did not resolve themselves in Vietnam, Afghanistan or Iraq. This is not a failure of the provisional organizations, but rather demonstrates the weakness of permanent, centralized bureaucracies and the organizational cultures they maintain. The assignment cycle and training were not the responsibilities of the theater level organizations of CORDS, NCT or ESC or the tactical level PRT. These responsibilities fall on the DOS's central headquarters in Washington D.C. This headquarters represents the organization's cultural hub. It is unlikely the DOS would completely change its organizational culture and ways of doing business simply to facilitate a few temporary

\footnotetext{
${ }^{72}$ Walter E. Natemeyer and Jay S. Gilberg, Classics of Organizational Behavior, 307.
} 
situations like Vietnam, Afghanistan and Iraq. If its ways of doing business are reasonably successful in most other situations the DOS finds itself in, then there is no reason to change its common practices to conform to irregular conflict, which is an uncommon event and will be different from location to location and era. However, what it does mean is that the DOS should be quick to employ ad hoc organizations when called upon in irregular war or counterinsurgency.

\section{Unified Command Structures}

The unfortunate difference between Vietnam and Afghanistan and Iraq is that it took the nation longer to integrate the DOS and the DOD, meaning the driver towards unity of effort is becoming slower. In the case of Vietnam it took thirty-four months from the time of major military involvement in 1964 to the consolidation of CORDS under MACV in 1967 (see Figure 2). Another forty-nine months elapsed between 1967 and 1971 when Nixon’s “Vietnamization Policy” handed most of the pacification and military operations back over to the RVN. In contrast, it took the USG forty-five months in Iraq and eighty-seven months in Afghanistan before the efforts introduced any serious political involvement on the part of the DOS. Afterwards it took an additional sixty months in Iraq and a projected seventy-two months in Afghanistan to turn the efforts back over to the host nation and remove the major military presence. 


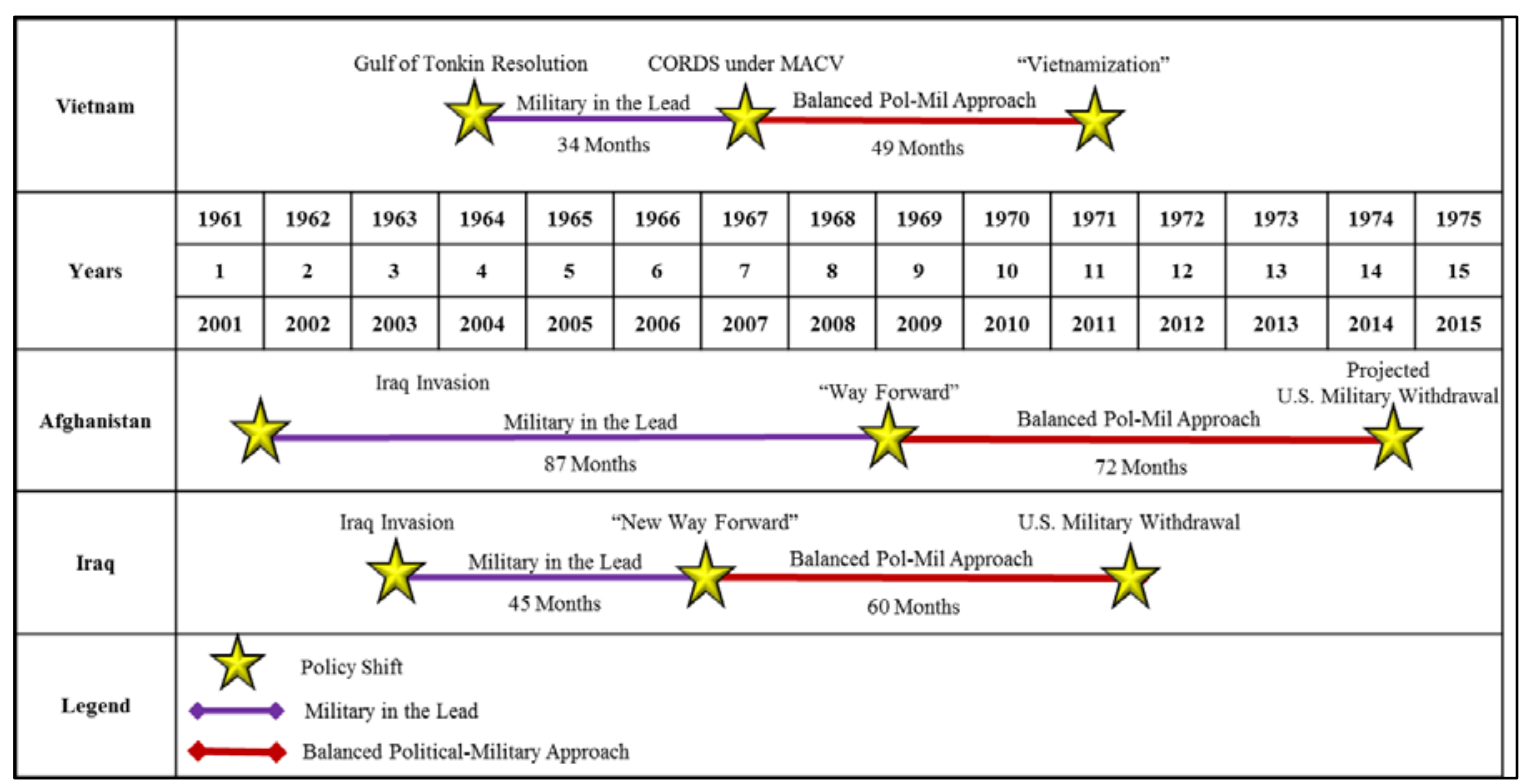

Figure 2. Comparative Timelines of Military-Led to Balanced Political-Military

Approaches.

Source: Created by author.

In Counterinsurgency Warfare: Theory and Practice David Galula states the purpose of an insurgency, a form of irregular warfare, is to dislocate the population from the government's control and win its active support. ${ }^{73}$ The primary operations of the counterinsurgent are not against the insurgent, but actively organizing the population in support of the government. ${ }^{74}$ Political operations, therefore, are the primary effort in counterinsurgencies, not military operations. However, political operations cannot take place without proper security. In The Logic of Violence in Civil War Stathis Kalyvas categorizes the disputed geographic terrain of an insurgency in a continuum of control from (1) strong government control, (2) secure government

${ }^{73}$ David Galula, Counterinsurgency Warfare: Theory and Practice (Lanham, MD: Praeger, 2006), 4.

${ }^{74}$ Ibid., 34. 
control, (3) contested areas, (4) secure insurgent control, to (5) strong insurgent control. ${ }^{75}$ Each side ultimately wants to expand its controlled areas at the expense of its adversary. The battlegrounds become the "contested areas" where each side wins the support of the population through a mixture of persuasion and coercion, requiring a balanced employment of political and military means.. Vietnam, Afghanistan and Iraq demonstrated that unity of command can occur between the DOS and the DOD to win these contested areas. The interagency unity of command structure in the two case studies demonstrates the importance of centralization at the theater level to enable decentralization at the tactical level. When higher level headquarters define their missions and priorities, this frees the lower units to execute those tasks. When mission and priorities are unresolved at the higher levels, paralysis at best and chaos at worst is inflicted on the lower levels responsible for execution of the mission. The unity of command has the added effect of demilitarizing the effort by making civilians prominent while reducing the role of the military to security matters..

These two case studies reveal that effective counterinsurgency did not get underway until there was a centralization of DOS and DOD efforts at the theater level. In Vietnam it was the formal subordination of CORDS under MACV. In Iraq it was the "New Way Forward” policy and informal agreement between the DOS and the DOD in the form of the UCP. A striking feature in the DOS evolution was the centralization of diplomatic and military commands at the theater level allowing decentralization at the tactical level. In Vietnam the locus of power emanated undoubtedly from Komer and the CORDS headquarters in Washington D.C. (strategic level) and his DepCORDS headquarters in Saigon (theater level). There were CORDS elements at the tactical level in the provinces and districts of Vietnam, but their consistent interaction with regular MACV forces was negligible. In Afghanistan and Iraq there was no Robert Komer.

${ }^{75}$ Stathis N. Kalyvas, The Logic of Violence in Civil War (New York: Cambridge University Press, 2006), 16. 
Certainly Ambassador Ryan Crocker's close partnership with General Petraeus enabled the reinvigorated counterinsurgency effort in Iraq in 2007, but the true power of the DOS effort resided in the PRTs located at the tactical level, where effective population influence took place. Although no formal command authority existed between PRTs and the units they supported, obstacles were resolved through personal interaction between PRT leaders and military commanders. Moreover, since each geographic area was different from one region to the next, the decentralization allowed specialization on local problems. A centralized headquarters attempting to resolve these unique problems would ultimately lead to ineffective, country-wide efforts that would not serve the specific requirements at the local level.

This trend toward decentralization and increased interagency partnership resolved the increasing militarization of the DOS which occurred in Vietnam. To paraphrase Clausewitz, the tendency in irregular conflicts is for the military to become more political in nature. ${ }^{76}$ Taking the opposite of that, the tendency for the DOS is to become more military in nature. The DOS was on the path of militarization in Vietnam due to MACV's indifference to the pacification effort. CORDS assumed militarized roles as head of rural security, eliminating VC agents under the Phoenix program and commanding military personnel who were assigned to the advisory teams. The DOS did not assume this level of militarization in Afghanistan or Iraq in the PRTs because they were collocated with brigades and regiments that provided security and advisory missions as part of their normal duties, alleviating the DOS of that function that it had previously assumed under the CORDS program. In Afghanistan and Iraq the military was deeply involved in developing indigenous security, developing the NATO Training Mission Afghanistan (NTMA) and the Multinational Security Transition Command Iraq (MSTC-I) to oversee training led by Military Transition Teams (MiTT) and Security Force Advisory and Assistance Teams (SFAAT).

\footnotetext{
${ }^{76}$ Clausewitz, On War, 87.
} 
These entities remained under military control. The DOS did retained some authority over military personnel assigned to PRTs, including proficiency reports, but legal matters of these personnel were controlled by the military. ${ }^{77}$

Invariably differences between the agencies arose due to organizational cultural differences that Schein describes as time and space perceptions. ${ }^{78}$ An organization's perception of time determines its actions depending on whether it has a short or long term view. The DOS and DOD differ on the idea of time because the decisive nature of the military causes it to have a short term view. Generally the military wants to win quickly, decisively and leave. The diplomat welcomes continuous engagement, reflecting a perpetual long term view. DOS critiques the military's approach to counterinsurgency as too rash, glossing over the major political issues in order to leave before the issue is resolved. The military criticizes the DOS's seeming inaction and apathetic nature. Space defines what responsibilities rest within an organization's acknowledged boundaries of responsibility. Interagency difficulties arise when one an agency is accused of “getting into my lane” by another agency. ${ }^{79}$ Time and space differences between the agencies were resolved through the decentralization of operations in theater. In Vietnam, Komer and Westmoreland were able to overcome their organizational cultural differences at the theater level because both men were professionals and realized there was more at stake than their agency’s organizational culture. This interagency conflict resolution mechanism was even more effective in Afghanistan and Iraq as operations were even more decentralized and PRT leaders had to work together with the brigade and regimental commanders at the tactical level to resolve differences

${ }^{77}$ Steven Mains, PRT Playbook: Tactics, Techniques, and Procedures (Leavenworth, KS: Center for Army Lessons Learned, 2013), 75.

${ }^{78}$ Schein, Organizational Culture and Leadership, 125.

${ }^{79}$ Ibid., 126. 
without theater level headquarters having to get involved.

\section{Local Solutions for Local Problems}

Two consistent features in the DOS evolution during irregular warfare are the use of host nation solutions to solve local problems and development of measurement tools to guide the effort. First, the DOS used local solutions to solve the immediate problems of the areas they are assigned. The liberal democratic nature of the U.S. supports the idea that local populations know best on how to guide their own affairs, roughly in line with the democratic peace theory. Democratic peace theory is the idea that democracies tend not to go to war with each other, which not only provides security, but sets up mutually beneficial relationships between nations. ${ }^{80}$ The liberal nature of U.S. foreign policy advances the idea that democratic values are generally universal values. Differences may exist between the supported population and accepted American values and norms, but these are resolved because the totality of democratization is of greater utility than letting a single issue derail the whole endeavor. Assisting a government conducting irregular warfare is ultimately most effective, not fighting it for them. As T.E. Lawrence observed in his dealings with Arab forces battling the Ottomans in World War I, “Do not try to do too much with your own hands. Better the Arabs do it tolerably than that you do it perfectly. It is their war, and you are to help them, not to win it for them." ${ }^{81}$ The DOS rightly avoids performing the role of governance for the country. This measure prevents perceptions of the United States supporting a puppet government in that country and also prevents host nation dependency on the United States.

\footnotetext{
${ }^{80}$ Paul Viotti and Mark Kauppi, International Relations Theory. $5^{\text {th }}$ ed. (New York: Pearson, 2012), 154.

${ }^{81}$ T.E. Lawrence, “The 27 Articles of T.E. Lawrence” (Arab Bulletin, August 20, 1917), http://modatraining.com/wp-content/uploads/2012/01/the-27-articles-of-t-e-lawrence.pdf (accessed January 2, 2014).
} 
In Vietnam, Afghanistan and Iraq the DOS was not doing anything revolutionary, they were simply putting extra effort behind programs initiated by the host nation. The main pacification programs supported by CORDS were initiated by Vietnam’s President Diem years before, including: rural security, enemy defection, anti-VCI, refugee resettlement, health and education. The CORDS program simply reinvigorated those projects by adding manpower and material to the effort. The same was true for the PRTs in Afghanistan and Iraq where the main purpose was capacity building for the host nation governments. The objective was to support the indigenous government to win the support of the people and achieve self-sufficiency. Since every region was different, allowing the native populations to decide what was best for their communities allowed the PRTs to orient on specific problems and set goals. Solving problems like livestock-to-feeding area ratios and providing different irrigation techniques showed what the PRTs were best suited for; helping and advising, but not performing the task.

The second feature of the DOS using host nation solutions is their ability to form tools to measure overall success of their programs. Measuring success in irregular conflicts is far more difficult than in traditional conflicts. In a traditional conflict a successful operation can be measured by territory covered or numbers of enemy forces destroyed. These factors generally lead to the adversary’s capitulation. In traditional war planning using Antoine-Henri Jomini’s planning framework uses lines of operation that "connects actions on nodes and/or decisive points related in time and space to an objective(s).” ${ }^{~} 2$ Lines of operation are useful against a traditional adversary where geographic points have meaning, but in an irregular conflict geographic points are largely irrelevant. Instead, lines of effort are used which "links multiple tasks and missions

${ }^{82}$ Baron De Jomini, The Art of War, Translated by G.H. Mendell and W.P. Craighill (Princeton, NJ: Bottom of the Hill Publishing, 2011), 39-50; United States Department of Defense, Joint Publication Joint Operation Planning (Washington, DC: CreateSpace Independent Publishing Platform, 2013), xxii. 
using the logic of purpose, cause and effect to focus efforts toward establishing operational and strategic conditions.”83

Reaching successful endstate conditions using lines of effort require ways to measure success of the effort. Organizations establish feedback mechanisms to identify if they are actually adapting successfully to the environment or not. Schein writes that "groups and organizations need to know how they are doing against their goals and periodically need to check to determine whether they are performing in line with their mission.” ${ }^{84}$ In Vietnam, CORDS used the HES to measure the pacification effort across Vietnam. In Afghanistan and Iraq, there were several tools to guide the PRT's counterinsurgency effort including the ICAF, TCAPF, and USAID's DSF. These tools helped to create the lines of effort based on measuring what was important to the indiginous government and population, called measures of effectiveness (MOEs), and then applied measurements against the MOEs to gauge how well those tasks were being executed, called measures of performance (MOPs). These tools allowed political and military planners to identify areas that were government controlled, insurgent controlled or contested. These tools allowed politial-military prioritization and syncrhonization of efforts. If an area was insurgent controlled, then the security situation generally prevented DOS involvement and military action was preminent. In a government controlled area, the DOS would reign with capacity building or reconstruction efforts while the miltiary involved itself as little as possible. In contested areas, a synchronized political-military effort was required to provide security while political measures were taken to gain the population's support in favor of the government.

\section{CONCLUSION}

The future is uncertain and the United States cannot rule out the possiblity of conducting

\footnotetext{
${ }^{83}$ Joint Chiefs of Staff, JP 5-0, xxii.

${ }^{84}$ Schein, Organizational Culture and Leadership, 83.
} 
stability operations with large military footprints. Vietnam, Afghanistan and Iraq illustrate the accidental nature nature in which the United States finds itself conducting stability operations. In each conflict the intervention transformed into something very different than originally intented. In each case the United States entered the conflict seeking to avoid protracted, nation-building exercises and astonishingly found itself doing just that. Wishing something will not happen is not a safe policy measure. Irregular conflicts will likely occur again, blurring the lines of where diplomacy ends and war begins. The DOS and the DOD are both organized to serve the American people, but the Constitution keeps them distinctly separate. Short of any sweeping legislation they will remain this way. The two organizations' purpose, organizational culture and history contribute to their differences which ultimately create a decisive and formal nature for DOD and a interminable and informal nature for the DOS. The understanding of diplomatic rule during peace and military rule during traditional warfare is upset in irregular warfare because it is in between general peace and general war and a political-military approach is required. Despite their differences, the DOS and DOD cooperation is essential to provide the political-military unity of effort required for irregular warfare. Since the DOS is not used to operating in a war zone, it must evolve to meet the challenges of the environment, which ultimately include creation of ad hoc organizations, establish unity of command with the military, and use of local solutions combined with tools to measure success.

In Vietnam the CORDS program represented the greatest example of organizational change in the DOS. It unified the pacification effort underneath a single manager, Rober Komer, who served under a military commander, General Westmoreland, but whose program commanded U.S. military personnel among its interagency composition. Komer reinvigorated RVN developed programs including rural security, reconstruction and resettlement and provided the HES to measure effectiveness. The American defeat in Vietnam was synonymous with nation-building and interagency cooperation languished in policies that avoided irregular warfare. 
This began to break down in the post-Cold War era as the United States became increasingly involved in stabilization efforts around the world. The attacks of 9/11 propelled the United States into stability operations once more in Afghanistan and Iraq in hopes of preventing continued failed state conditions that led to Islamic-inspired terrorist attacks agasint the United States. Unfortunately, two protracted insurgencies were the result, requiring a whole-of-government approach to quell the uprisings. The PRT represented the DOS's greatest organizational change in these conflicts. Partnered with U.S. Army brigades and USMC regiments, these orgnanizations provided the political element to the irregular conflict by building partnered government capacity and reconstruction to bolster the local and provincial governments. To guide the efforts, the DOS developed a number of tools to measure the counterinsurgency effort to include the ICAF, TCAPF and DSF.

A number of insights are uncovered when the two case studies coverd in this monograph are compared and contrasted against one another. Ad hoc organizations are ideal to overcome traditional organizational cultural barriers that prevent adaptation to the environment. Common practices that could not be overcome are beyond the influence of those organizations and that responsibility rests with the central headquarters in Washington D.C. The unified command structure between the DOD and DOS demonstrates the requirement for centralization at the theater level to allow decentralization at the tactical level. The increased decentralization in Afghanistan and Iraq prevented the militarization of the DOS that occured in Vietnam. The established unity of effort which was formal in Vietnam but informal in Afghanistan and Iraq allowed the diplomats to obtain a preeminant position in the conflict. This supports the concept that irregular conflicts are more political in nature and necessarily require the DOS to have the more dominant role. The DOS used host nation solutions because it supports the democratic nature of the United States to back the host nation's policy desires. It is careful not to perform the role of governance for the nation and allows the host nation to work through the problem on its 
own. The DOS correctly uses measurement tools to guide the counterinsurgency effort because metrics of success are so difficult to ascertain in an irregular conflict where geographic points are largely irrelevant. Metrics help identify government controlled, insurgent controlled and contested areas which subsequently direct military and political operations as necessary.

If the DOS and the DOD drift apart after Afghanistan and Iraq as they did after Vietnam, it is to the U.S. Army professionals' advantage to understand the DOS partner they may have to work with in the future. Diplomats can operate in war zones just as soldiers can attend diplomatic functions. The difference is that naturally the military presides in war while the diplomat rules in peace. As with any evolutionary process, the diplomat must adapt to the new environment to be successful. The soldier must be aware of these changes to ensure interagency unity of effort is maintained and strategic aims are achieved. 
APPENDIX A: TIMELINE

\begin{tabular}{|c|c|c|c|c|c|}
\hline \multirow{2}{*}{$\begin{array}{l}\text { Vietnam } \\
\text { - JAN. JFK supports GVN } \\
\text { counterinsurgency campaign } \\
\text { - Agrovilles established - GVN } \\
\text { resettlement program }\end{array}$} & \multicolumn{3}{|l|}{ Years } & \multirow{2}{*}{\begin{tabular}{|l|} 
Afghanistan \\
- SEP 11. Terrorists attack US \\
- OCT 7. Afghanistan invasion
\end{tabular}} & \multirow[t]{2}{*}{ Iraq } \\
\hline & 1961 & 1 & 2001 & & \\
\hline & 1962 & 2 & 2002 & $\begin{array}{l}\text { - Coalition Humanitarian } \\
\text { Liaison Cells established by } \\
\text { U.S. Army CA Teams }\end{array}$ & \\
\hline \multirow{2}{*}{$\begin{array}{l}\text { - NOV 2. Diem assassinated } \\
\text { - NOV 23. JFK assassinated } \\
\text { - Chieu Hoi established - GVN defection } \\
\text { program }\end{array}$} & \multirow[b]{2}{*}{1963} & \multirow[b]{2}{*}{3} & \multirow[b]{2}{*}{2003} & \multicolumn{2}{|c|}{$\begin{array}{l}\text { - JAN. NSPD } 24 \text { - DOD in the lead of post-conflict Iraq } \\
\text { reconstruction }\end{array}$} \\
\hline & & & & $\begin{array}{l}\text { - Afghanistan becomes } \\
\text { secondary effort }\end{array}$ & $\begin{array}{l}\text { - JAN. ORHA established } \\
\text { - } \text { MAR 20. Iraq invasion } \\
\text { - } \text { APR. ORHA dissolved, CPA } \\
\text { established } \\
\end{array}$ \\
\hline \multirow{2}{*}{$\begin{array}{l}\text { - AUG 7. Gulf of Tonkin Resolution } \\
\text { - "Americanization” of the conflict } \\
\text { - Search and Destroy strategy - } \\
\text { militarization of the conflict }{ }^{85}\end{array}$} & \multirow[b]{2}{*}{1964} & \multirow[b]{2}{*}{4} & \multirow[b]{2}{*}{2004} & \multicolumn{2}{|c|}{$\begin{array}{l}\text { - MAY. NSPD } 36 \text { - DOS in the lead of Iraq reconstruction. } \\
\text { - JUL - DOS S/CRS established }\end{array}$} \\
\hline & & & & & $\begin{array}{l}\text { - IRMO established } \\
\text { - PCO established } \\
\text { - SETs introduced } \\
\text { - APR. Battle of Fallujah }\end{array}$ \\
\hline \multirow[t]{3}{*}{$\begin{array}{l}\text { - Central Revolutionary Development } \\
\text { Council - GVN development program }\end{array}$} & \multirow[b]{2}{*}{1965} & \multirow[b]{2}{*}{5} & \multirow[b]{2}{*}{2005} & \multicolumn{2}{|c|}{$\begin{array}{l}\text { - DEC. NSPD } 44 \text { - DOS in the lead of all USG Stability and } \\
\text { Reconstruction Operations (SROs) and Afghanistan reconstruction }\end{array}$} \\
\hline & & & & - ESC established & $\begin{array}{l}\text { - NCT established } \\
\text { - PRDC established } \\
\text { - PRTs established }\end{array}$ \\
\hline & 1966 & 6 & 2006 & - Taliban resurgence & - 34,500 civilian fatalities \\
\hline $\begin{array}{l}\text { - MAY. CORDS subordinated to MACV } \\
\text { - JCS/MACV Combine Campaign Plan } \\
\text { - Pacification program invigorated }\end{array}$ & 1967 & 7 & 2007 & & $\begin{array}{l}\text { - "New Way Forward" - Surge } \\
\text { - OPA established } \\
\text { - PRTs embedded with } \\
\text { BDEs/RCTs } \\
\end{array}$ \\
\hline $\begin{array}{l}\text { - JAN 31. Tet Offensive } \\
\text { - HES - 59\% of South Vietnamese feel } \\
\text { secure } \\
\text { - NOV. Nixon elected president } \\
\text { - "Vietnamization" policy } \\
\end{array}$ & 1968 & 8 & 2008 & - ICAF created. & $\begin{array}{l}\text { - Assisting PRTs is the "primary } \\
\text { effort" - Odierno }\end{array}$ \\
\hline \multirow[t]{2}{*}{$\begin{array}{l}\text { - JAN. Pacification is "really the most } \\
\text { important thing we are doing"86 - } \\
\text { Abrams }\end{array}$} & 1969 & 9 & 2009 & $\begin{array}{l}\text { - DEC. "Way Forward” - Surge } \\
\text { - 2,412 civilian fatalities }\end{array}$ & - 3,000 civilian fatalities \\
\hline & 1970 & 10 & 2010 & & \\
\hline \multirow[t]{2}{*}{$\begin{array}{l}\text { - HES. 96\% of South Vietnamese feel } \\
\text { secure }\end{array}$} & 1971 & 11 & 2011 & & - DEC. US withdrawal from Iraq \\
\hline & 1972 & 12 & 2012 & - 1,145 civilian fatalities & \\
\hline \multirow[t]{2}{*}{$\begin{array}{l}\text { - JAN 27. Paris Peace Accords signed. } \\
\text { - U.S. begins withdrawal from Vietnam }\end{array}$} & 1973 & 13 & 2013 & & \\
\hline & 1974 & 14 & 2014 & $\begin{array}{l}\text { - DEC. Projected withdrawal } \\
\text { from Afghanistan }\end{array}$ & \\
\hline - APR 30. Communists seize Saigon & 1975 & 15 & 2015 & & \\
\hline
\end{tabular}

${ }^{85}$ John H. Hay, Vietnam Studies Tactical and Material Innovations (Washington, DC: Department of the Army, 1974), 169.

${ }^{86}$ Hunt, Pacification: the American Struggle for Vietnam's Hearts and Minds, 193. 


\section{APPENDIX B: GLOSSARY}

capacity building - The process of creating an environment that fosters host-nation institutional development, community participation, human resources development, and strengthening of managerial systems. (FM 3-07)

counterinsurgency - Comprehensive civilian and military efforts designed to simultaneously defeat and contain insurgency and address its root causes. Also called COIN. (JP 3-24)

insurgency - An organized movement aimed at the overthrow of a constituted government through use of subversion and armed conflict. (JP 3-05)

intelligence (joint) - The product resulting from the collection, processing, integration, evaluation, analysis, and interpretation of available information concerning foreign nations, hostile or potentially hostile forces or elements, or areas of actual or potential operations. The term is also applied to the activity which results in the product and to the organizations engaged in such activity. (JP 2-0)

interagency (joint) - United States Government agencies and departments, including the Department of Defense. (JP 3-08)

interagency coordination (joint) - Within the context of Department of Defense involvement, the coordination that occurs between elements of Department of Defense and engaged U.S. Government agencies for the purpose of achieving an objective. (JP 3-0)

intergovernmental organization (joint) - An organization created by a formal agreement (e.g., a treaty) between two or more governments. It may be established on a global, regional, or functional basis for wide-ranging or narrowly defined purposes. Formed to protect and promote national interests shared by member states. Examples include the United Nations, North Atlantic Treaty Organization, and the African Union. (JP 3-08)

irregular warfare - Irregular warfare is characterized as a violent struggle among state and nonstate actors for legitimacy and influence over the relevant population(s). In IW, a less powerful adversary seeks to disrupt or negate the military capabilities and advantages of a more powerful military force, which usually serves that nation's established government. (JP 1)

stability operations - Stability operations are various military missions, tasks, and activities conducted outside the US in coordination with other instruments of national power to maintain or reestablish a safe and secure environment, provide essential governmental services, emergency infrastructure reconstruction, and humanitarian relief. (JP 3-07)

traditional warfare - Traditional warfare is characterized as a violent struggle for domination between nation-states or coalitions and alliances of nation-states. With the increasingly rare case of formally declared war, traditional warfare typically involves force-on-force military operations in which adversaries employ a variety of conventional forces and special operations forces (SOF) against each other in all physical domains as well as the information environment (which includes cyberspace). (JP 1) 


\section{BIBLIOGRAPHY}

Adkin, Mark. Urgent Fury: the Battle for Grenada: the Truth Behind the Largest U.S. Military Operation Since Vietnam. London: Trans-Atlantic Pubns Inc, 1989.

“An Interview with Raymond T. Odierno.” Prism 1, no. 2 (March, 2010): 141-48. http://cco.dodlive.mil/files/2013/08/prism1-2.pdf (accessed December 18, 2013).

Brafman, Ori, and Rod A. Beckstrom. The Starfish and the Spider: The Unstoppable Power of Leaderless Organizations. London: Portfolio Trade, 2008.

Bush, George W. “A Period of Consequences.” Lecture, The Citadel, Charleston, SC, September 23, 1999. http://www3.citadel.edu/pao/addresses/pres_bush.html (accessed December 16, 2013).

Clausewitz, Carl von. On War, Edited and Translated by Michael Howard and Peter Paret. Princeton, NJ: Princeton University Press, 1989.

Center For Army Lessons Learned. The Iraq Provincial Reconstruction Team Handbook: Observations, Insights, and Lessons. Leavenworth, KS: Center for Army Lessons Learned, November 2010. http://usacac.army.mil/cac2/call/docs/11-03/11-03.pdf (accessed August 10, 2013).

. The Afghanistan Provincial Reconstruction Team Handbook: Observations, Insights, and Lessons. Leavenworth, KS: Center for Army Lessons Learned, February 2011. http://usacac.army.mil/cac2/call/docs/11-16/11-16.pdf (accessed August 10, 2013).

Commission on Wartime Contracting in Iraq and Afghanistan, (U.S.), ed. Transforming Wartime Contracting: Controlling Costs, Reducing Risks. Washington, DC: US Independent Agencies and Commissions, 2011.

Christoff, Joeseph. Provincial Reconstruction Teams in Afghanistan and Iraq. Washington, DC: Government Accountability Office, 2008. http://www.gao.gov/new.items/d0986r.pdf (accessed February 5, 2014).

Department of the Army, Field Manual 3-24 Counterinsurgency Operations (U.S. Army Field Manual). Washington, DC: Headquarters, Marine Corps Combat Development Command, 2006.

Derleth, James. “The Tactical Conflict Assessment.” Lecture, PPC Conference Room, January 5, 2009. http://pdf.usaid.gov/pdf_docs/PNADN621.pdf (accessed December 18, 2013).

Echevarria, Antulio. An American Way of War or Way of Battle? Carlisle: Strategic Studies Institute, 2004. http://www.strategicstudiesinstitute.army.mil/pdffiles/pub662.pdf (accessed January 2, 2014).

Executive Office of The President of the United State. The National Security Strategy of the United States of America: September 2002. Washington, DC: CreateSpace Independent Publishing Platform, 2012.

Galula, David. Counterinsurgency Warfare: Theory and Practice. Lanham, MD: Praeger, 2006. 
Hay, John H. Vietnam Studies Tactical and Material Innovations. Washington, DC: Department of the Army, 1974.

Hulen, Bertram. Inside the Department of State. New York: Whittlesey House, 1939.

Hunt, Gaillard. "History of the State Department." The American Journal of International Law 3, no. 1 (January 1909): 137-62. http://www.jstor.org/stable/2186211 (accessed January 2, 2014).

Hunt, Richard A. Pacification: The American Struggle for Vietnam's Hearts and Minds. Boulder: Westview Press, 1995.

Kalyvas, Stathis N. The Logic of Violence in Civil War. New York: Cambridge University Press, 2006.

Komer, Robert. Bureaucracy Does Its Thing: Institutional Constraints On US-GVN Performance in Vietnam. Santa Monica, CA: Defense Advanced Research Projects Agency, Rand Corporation, August 1972.

Krepinevich Jr., Andrew F. The Army and Vietnam. Baltimore, MD: Johns Hopkins University Press, 1988.

Jomini, Baron De, The Art of War, Translated by G.H. Mendell and W.P. Craighill. Princeton, NJ: Bottom of the Hill Publishing, 2011.

Lamb, Christopher. Redesigning White House and Interagency Structures. In Civilian Surge: Key to Complex Operations, edited by Hans Binnendijk and Patrick Cronin, 19-38.

Washington, DC: The National Defense University, December, 2008.

Lawrence, T.E. “The 27 Articles of T.E. Lawrence.” Arab Bulletin, August 20, 1917. http://modatraining.com/wp-content/uploads/2012/01/the-27-articles-of-t-e-lawrence.pdf (accessed January 2, 2014).

Lehman, Herbert. “Address Given by Herbert H. Lehman.” Lecture, Office of Foreign Relief and Rehabilitation Operations, Washington, DC, June 17, 1943. http://www.cvce.eu/ content/publication/2002/10/14/f71e490b-204a-405d-92d8-936a1b8150e0/pub lishable_en.pdf (accessed January 28, 2014).

Mains, Steven. PRT Playbook: Tactics, Techniques, and Procedures.Leavenworth, KS: Center for Army Lessons Learned, 2013.

Natemeyer, Walter E., and Jay S. Gilberg. Classics of Organizational Behavior. 2nd ed. Danville, IL: North Amer Training \& Development, 1989.

Office of the Coordinator for Reconstruction and Stabilization. "Interagency Conflict Assessment Framework (ICAF).” Washington, DC: United States Department of State, November 2010. http://www.state.gov/documents/organization/187786.pdf (accessed December 18, 2013). 
Office of Military Affairs (OMA). “Tactical Conflict Assessment and Planning Framework.” Washington, DC: United States Agency of International Development, 2010. http://pdf.usaid.gov/pdf_docs/Pnadn621.pdf (accessed December 18, 2013).

Perito, Robert M. The U.S. Experience with Provincial Reconstruction Teams in Afghanistan: Lessons Learned. United State Institute of Peace: Special Report, October 2005. http://www.usip.org/sites/default/files/sr152.pdf (accessed December 18, 2013).

Phillips, R. Cody. Operation Just Cause: The Incursion Into Panama. Washington, DC: The U.S. Army Center for Military History, 2012. http://www.history.army.mil /brochures/ Just\%20Cause/JustCause.html (accessed December 16, 2013).

Ramsey III, Robert D. Savage Wars of Peace: Case Studies of Pacification in the Philippines, 1900-1902: The Long War Series Occasional Paper 24. Leavenworth, KS: Combat Studies Institute, 2012.

Rife, Rickey. "Defense Is from Mars, State Is from Venus: Improving Communications and Promoting National Security.” Carlisle: U.S. Army War College, 1998.

Schein, Edgar H. Organizational Culture and Leadership. 4th ed. San Francisco, CA: JosseyBass, 2010.

Simpson, Emile. War from the Ground Up: Twenty-First Century Combat as Politics. New York: Columbia University Press, 2012.

Special Inspector General for Iraq Reconstruction. Applying Iraq's Hard Lessons to the Reform of Stabilization and Reconstruction Operations. SIGIR, February 2010. http://www.sigir.mil/files/USOCO/ApplyingHardLessons.pdf (accessed November 10, 2013).

Stuart, Graham H. The Department of State: A History of Its Organization, Procedure and Personnel. New York: The Macmillan Co., 1949.

Terrell, John Upton. The United States Department of State: A Story of Diplomats, Embassies, and Foreign Policy. New York: Meredith Press, 1968.

Tran, Dinh Tho. Pacification. Washington, DC: U.S. Army Center of Military History, 1980.

U.S. Embassy Saigon. A Preliminary Report On Activities During the 1969 Autumn Campaign. Saigon: Vietnam Documents and Research Notes No. 82, July 1972.

United States Agency for International Development. "The District Stability Framework.” USAID. February, 2013. http://www.usaid.gov/work-usaid/partnership-opportunities/usmilitary/training/district-stability-framework (accessed December 18, 2013).

Joint Chiefs of Staff. U.S. Army. Joint Publication 1 Doctrine for the Armed Forces of the United States. 25 March 2013. Washington, DC: CreateSpace Independent Publishing Platform, 2013. 
. U.S. Army. Joint Publication 1-02 Department of Defense Dictionary of Military and Associated Terms. 15 August 2012. Washington, DC: CreateSpace Independent Publishing Platform, 2012.

U.S. Army. Joint Publication 3-07: Stability Operations. Washington D.C.: CreateSpace Independent Publishing Platform, September 29, 2011.

Joint Publication 5-0: Joint Operation Planning. Washington D.C.: CreateSpace Independent Publishing Platform, 2013.

Viotti, Paul and Mark Kauppi, International Relations Theory. $5^{\text {th }}$ ed. New York: Pearson, 2012

Weinberger, Caspar. “The Uses of Military Power.” Lecture, The National Press Club, Washington, DC, November 28, 1984. http://www.pbs.org/wgbh/pages/frontline /shows/military/force/weinberger.html (accessed December 16, 2013).

The White House. "PDD/NSC 56: The Clinton Administration’s Policy On Managing Complex Contingency Operations.” Presidential Decision Directives - PDD. 1997. https://www.fas.org/irp/offdocs/pdd56.html (accessed December 16, 2013). 